\title{
Geochemical mapping based on regularly spaced composite stream sediment samples produced from stored aliquots - State of Paraná pre-Cambrian Shield, Brazil
}

Fabio Luigi Crisigiovanni ${ }^{1}$ Otavio Augusto Boni Licht ${ }^{1 *}$ Viviane Carillo Ferrari ${ }^{2}$ Claudio Gerheim Porto ${ }^{3}$

${ }^{1}$ Programa de Pós-graduação em Geologia Universidade Federal do Paraná Centro Politécnico

Av. Cel. Francisco H dos Santos, 100 Jardim das Américas Curitiba PR Brazil CEP 81530-000

${ }^{2}$ Serviço Geológico do Brasil - SGB-CPRM Superintendência de São Paulo Rua Costa, 55

Consolação
São Paulo SP Braz

CEP 01304-010

${ }^{3}$ Serviço Geológico do Brasil - SGB-CPRM Divisão de Geoquímica Avenida Pasteur, 404 Avenid

Urca

Rio de Janeiro R, Brazil CEP 22290-255

${ }^{3}$ Current address:

Universidade Federal do Rio de Janeiro Instituto de Geociências Departamento de Geologia

Av. Athos da Silveira Ramos, 274

Av. Athos da Silveira Ramos, 274, Cidade Universitária, Ilha CEP 21949-900

* Corresponding author otavio.licht@gmail.com

\section{RESUMO}

Uma coleção de 6.587 amostras de sedimentos fluviais ativos cobrindo cerca de $4.800 \mathrm{~km}^{2}$ no Escudo do Paraná, no sul do Brasil, foi usada para produzir 75 amostras compostas, cada uma representando uma célula de 5' x 5'. As amostras originais foram recuperadas dos arquivos do Serviço Geológico do Paraná - MINEROPAR e do Serviço Geológico do Brasil - SGB / CPRM. As amostras compostas foram submetidas a quatro procedimentos analíticos com a determinação de 66 elementos. Os mapas geoquímicos dos elementos isolados, bem como a análise de correlação bivariada, mostraram seis associações entre elementos, cada uma refletindo a herança geoquímica de litologias específicas e pelo menos uma área com alto potencial exploratório, anteriormente desconhecida dada a pequena quantidade de elementos analisados nas amostras originais. Os mapas geoquímicos foram produzidos pela classificação das células (mapas de pixels) ou pela aplicação de interpolação com a mínima curvatura, considerada como o melhor interpolador para a geração dos mapas de isógradas (mapas vetoriais). A comparação entre amostras compostas e originais mostrou que, mesmo com diferentes técnicas analíticas, o teor dos elementos nas amostras compostas é semelhante à média do teor nas amostras originais em cada célula. Os resultados obtidos nos permitem recomendar a adoção deste conjunto de procedimentos em coletas de amostras de sedimentos fluviais cobrindo grandes áreas, com pelo menos três vantagens: (a) eliminar custos de campo recuperando amostras já coletadas e arquivadas, (b) reduzir a quantidade de amostras a serem analisadas e (c) minimizar quaisquer erros de posicionamento das estações de amostragem, coletadas antes do advento do equipamento GPS. A verificação e detalhamento das áreas de interesse evidenciadas por este procedimento podem ser feitas facilmente com a análise das amostras originais ainda armazenadas nas coleções.

Palavras-chave: mapeamento geoquímico, geoquímica multipropósito, amostras compostas

\section{ABSTRACT}

A collection of 6,587 active stream sediment samples covering about 4,800 $\mathrm{km}^{2}$ in the Paraná Shield, southern Brazil was used to produce 75 composite samples each representing a 5' x 5' cell. The original samples were retrieved from the archives of the Geological Service of Paraná - MINEROPAR and the Geological Service of Brazil - SGB / CPRM. The composite samples were submitted to four analytical methods with the determination of 66 elements. Geochemical maps of the isolated elements along with bivariate correlation analysis showed six associations between elements, each representing specific lithologies and at least one area with high exploratory potential, which was previously unknown given the small amount of elements analyzed in the original samples. The geochemical maps were produced either by cell classification (pixel maps) or by the application of the minimum 
curvature interpolation method, considered as the best interpolator for the generation of the isograd maps (vector maps). The comparison between composite and original samples showed that, even with different analytical techniques, the element contents of the composite samples are similar to the average of the contents in the original samples on each cell. The results obtained allow us to recommend the adoption of this set of procedures in stream sediment sample collections covering large areas, with at least three advantages of: (a) eliminating field costs by retrieving already collected and archived samples, (b) reducing the amount of samples to be analyzed and (c) minimize any positioning errors of sampling sites collected before the advent of GPS equipment. The verification and detailing of the areas of interest evidenced by this procedure can be done easily with the analysis of the original samples still stored in the collections.

Keywords: geochemical mapping, multi-purpose geochemistry, composite samples

\section{INTRODUCTION}

In the State of Paraná, mainly in the preCambrian Shield, mineral exploration surveys were carried out in the 1970 s, 1980s and the beginning of the 1990 s by many state owned organizations like Departamento Nacional da Produção Mineral (National Department of Mineral Production) DNPM, Serviço Geológico do Brasil (Brazil Geological Survey) CPRM, Petrobrás Mineração S.A. (Petrobras Mining) PETROMISA, Companhia Nacional de Energia Nuclear (Brazilian Nuclear Company) NUCLEBRÁS and Serviço Geológico do Paraná (State of Paraná Geological Survey) MINEROPAR

Despite the large amount of data produced by these surveys at the time, almost all stream sediments samples were analyzed only for $\mathrm{Cu}$, $\mathrm{Pb}, \mathrm{Zn}, \mathrm{Ni}, \mathrm{Co}, \mathrm{Fe}$ and $\mathrm{Mn}$ mostly due to limited analytical techniques. In very restricted areas, $\mathrm{Au}, \mathrm{F}, \mathrm{Mo}, \mathrm{Sn}$ and $\mathrm{W}$ were also analyzed. After the analytical procedures, the dry pulps $(<80 \#)$ were carefully stored. It is important to emphasize that under subtropical climate with wet season concentrated on the hot summer, as in the case of the study area, the geochemical processes of mobilization and transport are mainly hydromorphic, making it is quite impossible to find sulfide grains released by exploratory targets in stream sediment samples. Under this regime, the highest contents of almost all elements, are found in the finer grain fractions.

Using this area as a test, Licht and Tarvainen (1996) showed how the integration of old exploration geochemistry data sets may be used to produce maps with multipurpose applications, e.g., mineral exploration, regional planning, identification and management of environmental liabilities and public health risk areas.

According to an international effort to establish global geochemical baselines, the International Union of Geological Sciences (IUGS) constituted the International Geological Correlation Program's (IGCP) Project 259, and published the final report "A Global Geochemical Database for Environmental and Resource Management" containing all field and laboratory protocols to be followed by all countries which wish to adhere to the project. One of the protocols determines that stream sediments samples should represent catchment basins which must be contained on $1^{\circ} 30^{\prime}$ square cells composing a global grid (Darnley et al. 1995; Smith et al. 2018).

By applying this general concept, the present research used the retrieval of ordinary stream sediments samples collected by previous surveys and appropriately stored, to produce composite samples representative of $5^{\prime}$ side sub-cells which were analyzed for 66 elements. This regular grid covers a large portion of the State of Paraná pre-Cambrian Shield also known as Paraná $1^{\text {st }}$ Plateau (Figure 1).

It is assumed that the analytical results are representative of the whole cell. The results of such new procedures and multi-element analytical techniques which had been applied to the composite samples will be tested and compared to verify its feasibility and reliability. 


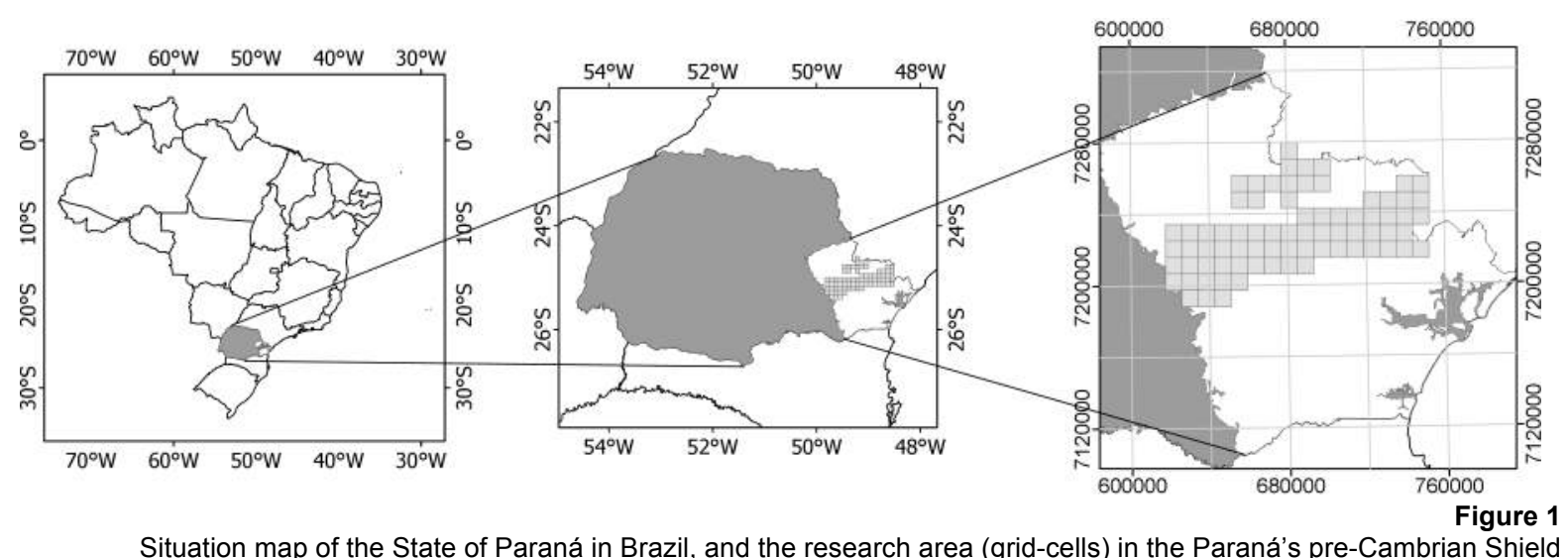

Situation map of the State of Paraná in Brazil, and the research area (grid-cells) in the Paraná's pre-Cambrian Shield

(Crisigiovanni 2016).

\subsection{A BRIEF GEOLOGICAL OVERVIEW}

The State of Paraná pre-Cambrian Shield is formed by igneous and metamorphic rocks ranging from Archean to Cambrian, locally covered with volcano-sedimentary sequences, sedimentary rocks and unconsolidated sediments (Figure 2). High grade metamorphic rocks, outcrop in the southeastern portion, and the low grade metamorphic, in the northnorthwest portion. In the Proterozoic, Cambrian, and in the early Paleozoic terrains, magmatic events gave rise to granitic intrusions. In the Mesozoic many intrusions of carbonatite, alkaline and basic rocks occurred. In the area covered by the present research, at least five ore types or models are known, (1) $\mathrm{Zn}-\mathrm{Pb}-\mathrm{Cu}-\mathrm{Ag}-\mathrm{Cd}$ sulfides; (2) REE and F hosted by alkaline rocks and carbonatites; (3) Fluorspar disseminations or veins in

\subsection{THE FORMER GEOCHEMICAL DATABASE}

As presented by Licht and Tarvainen (1996), the data base covering the Paraná preCambrian Shield was composed by the integration of geochemical data from 42 surveys. Almost all samples were sieved at $<80$ mesh $(<0.162 \mathrm{~mm})$ and analyzed by atomic absorption after aqua regia digestion. The number of samples and the analyzed elements

\subsection{HYPOTHESIS}

The working hypothesis for this research was: would the concept proposed by the IGCP259 Project for geochemical mapping on a

\subsubsection{OBJECTIVES}

The main objectives of this research were: (1) to produce a multielement geochemical database of the Pre-Cambrian Shield of Paraná, metamorphic limestone roof-pendants hosted by the Três Córregos granite; (4) Sulfide $\mathrm{Au}$ and (5) Pt-Pd in meta-basic or meta-ultrabasic rocks.

In the region there are large tectonic lineaments extending hundreds of kilometers of Brazilian Cycle and even younger, since they affect the granites intruded in this period. The main faults are Northeast transcurrent, typically anastomosed, with movements of the order of hundreds of kilometers that would have been responsible for the development of cataclasites and lenticularization of geological units and the narrow and elongated forms of the sin- and late-tectonic granites which are present in this region (Fiori et al. 1984; Fiori 1985).

in each survey are presented in Tables 1 and 2 and their spatial distribution is shown in Figure 6. A summary of this research may be found in Licht (2018). Even considering these discrepancies it was possible to compare the results and geochemical maps produced with this old geochemical data set with the new multi-element database.

global scale, be applicable on a much more detailed scale with reliable results?

applying the concept of the Global Geochemical Reference Network (GGRN) proposed by the IGCP-259. (2) To test the 
feasibility of producing a reliable geochemical database using composite samples according to a regular grid, retrieving old stream sediment samples appropriately stored and (3) Is it feasible to apply these procedures in other regions aiming the optimization of financial resources?

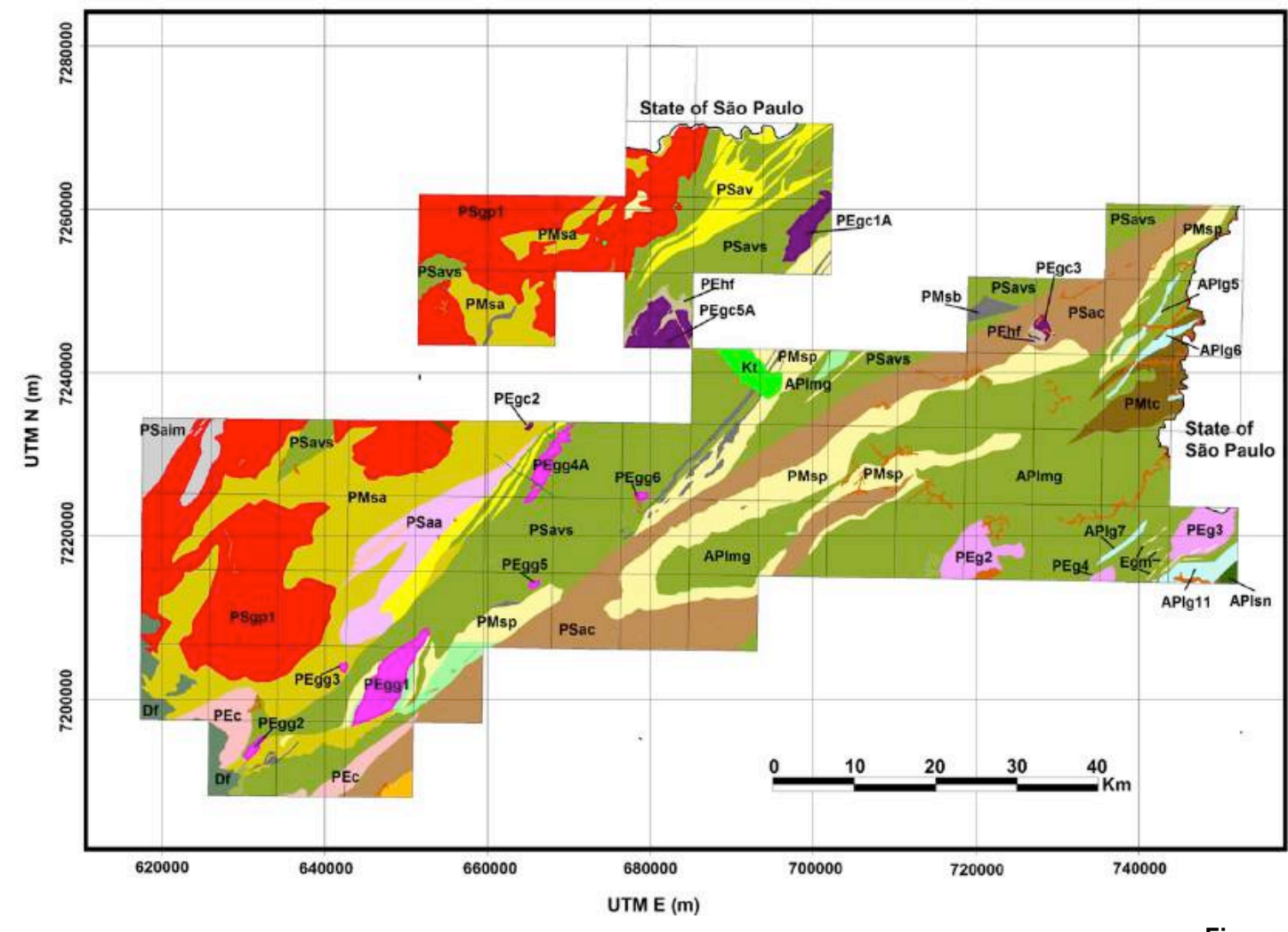

Simplified geological map of the working area (after MINEROPAR 2006)

Key:

Lower Proterozoic: APIg4 Areia Branca granite, APIg5 Vaguaçu granite, APIg6 Nagib Silva granite, APIg7 Faxinal granite, APIg11 Tagaçaba granite (Granite-gneiss Complex); APImg Gneiss-migmatite Complex; APIsn Serra Complex. Mesoproterozoic: PMtc Turvo Cajati Complex; PMspc Perau Formation; PMsac Agua Clara Formation. Neoproterozoic: PMsavc Votuverava Formation; PSaaA1 Antinha Formation; PSacdc Capiru Formation; Itaiacoca Formation; PSgp1 Três Córregos granite (Monzogranite Suite); PSmb Metabasics; PEc Camarinha Formation.

Precambrian: PEgc1A Varginha granite, PEgc2 Taici granite, PEgc3 Banhado granite, PEgc5A Morro Grande granite (Monzogranite Suite); PEgg1 Cerne granite, PEgg2 Passa Três granite, PEgg3 Chacrinha granite, PEgg4A Piedade granite, PEgg5 Rio Abaixo granite, PEgg6 Pula Sapo granite (Syenogranite Suite); PEg2 Graciosa granite, PEg3 Alto Turvo granite, PEg4 Rio do Salto granite, Alkali-granite Suite;

PEhf Hornblende-hornfels Facies.

Cambrian: Egm Acidic intrusives

Devonian: DF Furnas Formation

Cretaceous: Kt Tunas Massif (Alkaline intrusives)

\section{MATERIALS AND METHODS}

To improve the spatial resolution of the results and the accuracy of their application, the Global Geochemical Reference Network (DARNLEY et al. 1995) was divided in $5^{\prime}(\approx 8$ $\mathrm{km})$ side sub-cells. The geographic reference of the original samples and sub-cells was converted to UTM SAD69. Thus geochemical maps are also referred to this coordinate system and datum.

\subsection{PREPARATION OF THE COMPOSITE SAMPLES}

The selected stream sediments samples, previously collected and stored by MINEROPAR (Figure 3) and SGB/CPRM, had already been disaggregated and sieved to minus $0,162 \mathrm{~mm}(<80 \mathrm{mesh})$ before analysis. 
Table 1 - Summary of analytical procedures for integrated stream sediment surveys. Analytical procedures: (1) aqua regia digestion atomic absorption; (2) $\mathrm{HNO}_{3}$ concentrate and hot digestion/atomic absorption; (3) colorimetry; (4) hydride generation/atomic absorption; (-) not analysed. After Licht \& Tarvainen (1996).

\begin{tabular}{|c|c|c|c|c|c|c|c|c|c|}
\hline \multirow[b]{2}{*}{ Company } & \multirow[b]{2}{*}{ Survey } & \multicolumn{8}{|c|}{ Elements / analytical procedures } \\
\hline & & $\mathbf{C u}$ & $\mathbf{P b}$ & Zn & $\mathbf{N i}$ & Co & $\mathrm{Fe}$ & Mn & As \\
\hline \multirow{20}{*}{ Mineropar } & Paraiso & (1) & (1) & - & - & - & - & - & - \\
\hline & Marquês de Abrantes & - & (1) & - & - & - & - & - & - \\
\hline & Nagib Silva & (1) & (1) & (1) & - & (1) & - & - & - \\
\hline & Tigre-Betara-Açungui & (1) & (1) & (1) & (1) & (1) & (1) & (1) & (4) \\
\hline & Formação Agua Clara & (1) & (1) & (1) & (1) & (1) & (1) & (1) & (1) \\
\hline & Caçador Jacui & (1) & (1) & (1) & (1) & (1) & (1) & (1) & (1) \\
\hline & Barra do Itapirapuã & (1) & (1) & (1) & (1) & (1) & (1) & (1) & (4) \\
\hline & São Silvestre & (1) & (1) & (1) & (1) & (1) & (1) & (1) & (1) \\
\hline & Volta Grande & (1) & (1) & (1) & - & - & (1) & (1) & (4) \\
\hline & Castro & (1) & (1) & (1) & (1) & (1) & (1) & (1) & (4) \\
\hline & Antinha & (1) & (1) & (1) & (1) & (1) & (1) & (1) & (4) \\
\hline & Capivari-Pardo (fill-in) & (1) & (1) & (1) & (1) & (1) & (1) & (1) & (4) \\
\hline & Canha-Carumbé & - & (1) & - & - & - & - & - & - \\
\hline & Guaratubinha & (1) & (1) & (1) & (1) & (1) & (1) & (1) & (4) \\
\hline & Anhangava & (1) & (1) & (1) & (1) & (1) & (1) & (1) & (4) \\
\hline & Capivara & (1) & (1) & (1) & - & - & (1) & (1) & - \\
\hline & Santana & (1) & (1) & (1) & - & - & (1) & (1) & - \\
\hline & Granitos & (1) & (1) & (1) & - & (1) & - & - & (4) \\
\hline & Capivari-Pardo (regional) & (1) & (1) & (1) & (1) & (1) & (1) & (1) & (4) \\
\hline & Vale do Ribeira & (2) & (2) & (2) & (2) & (2) & (2) & (2) & - \\
\hline \multirow{2}{*}{ DNPM-CPRM } & Guaratubinha-Piên & (2) & (2) & (2) & (2) & (2) & - & - & (3) \\
\hline & Castro-Piraí & (2) & (2) & (2) & (2) & (2) & (2) & (2) & (3) \\
\hline \multirow{2}{*}{ Petromisa } & Furnas-Ponta Grossa & (2) & (1) & (1) & (1) & (1) & (1) & (1) & - \\
\hline & Furnas-Ponta Grossa (fill in) & (2) & (2) & (2) & - & - & - & - & (2) \\
\hline \multicolumn{2}{|c|}{ Total amount in the integrated database } & 14,746 & 15,267 & 14,694 & 9,117 & 9,026 & 7,831 & 7,876 & 7,351 \\
\hline
\end{tabular}

Table 2 - Summary of integrated fluorine stream sediment and pan concentrate surveys. All samples were analysed by alkali fusion/specific ion electrode. After Licht \& Tarvainen (1996)

$\begin{array}{ccc}\text { Company } & \text { Survey } & \text { Type of sample } \\ \text { Paraíso } & \text { Pan concentrate } \\ \text { Cantagalo } & \text { Pan concentrate } \\ \text { Nagib Silva } & \text { Stream sediment } \\ \text { Mineropar } & \text { Barra do Itapirapuã } & \text { Stream sediment } \\ & \text { Volta Grande } & \text { Pan concentrate } \\ & \text { Volta Grande } & \text { Stream sediment } \\ & \text { Capivari-Pardo (fill-in) } & \text { Pan concentrate } \\ \text { Canha-Carumbé } & \text { Pan concentrate } \\ & \text { Anhangava } & \text { Pan concentrate } \\ \text { Granitos } & \text { Pan concentrate } \\ & \text { Capivari Pardo } & \text { Pan concentrate } \\ & \text { Data in the integrated database } & \mathbf{2 , 2 7 0}\end{array}$

Thus the $<80 \#$ pulps of the original samples contained in each sub-cell were retrieved from the archives (Figure 3) and an almost similar portion of each put into a numbered plastic container, thus setting the composite sample of each sub-cell (Figure 4). During preparation of the composite samples, proper procedures were adopted to minimize sample contamination such as having the exhaust fan turned on and carefully cleaning the workbench (Figure 5).

The set of original samples of each sub-cell was then homogenized, passing four times on a stainless-steel Jones riffle splitter, being one fourth of it sent to the laboratory. Following this procedure, 9,030 original samples were handled, giving rise to 93 composite samples (Figure 6). In order to present geochemical maps with geographic continuity allowing correlations and cause-effect conclusions related to the geological landscape, the isolated cells were disregarded, being selected only 75 sub-cells which were produced using 7,428 original samples (Figure 6 right). Thus, this is the set of geochemical data with which all data treatments, correlations, maps and conclusions will be made in this article. 

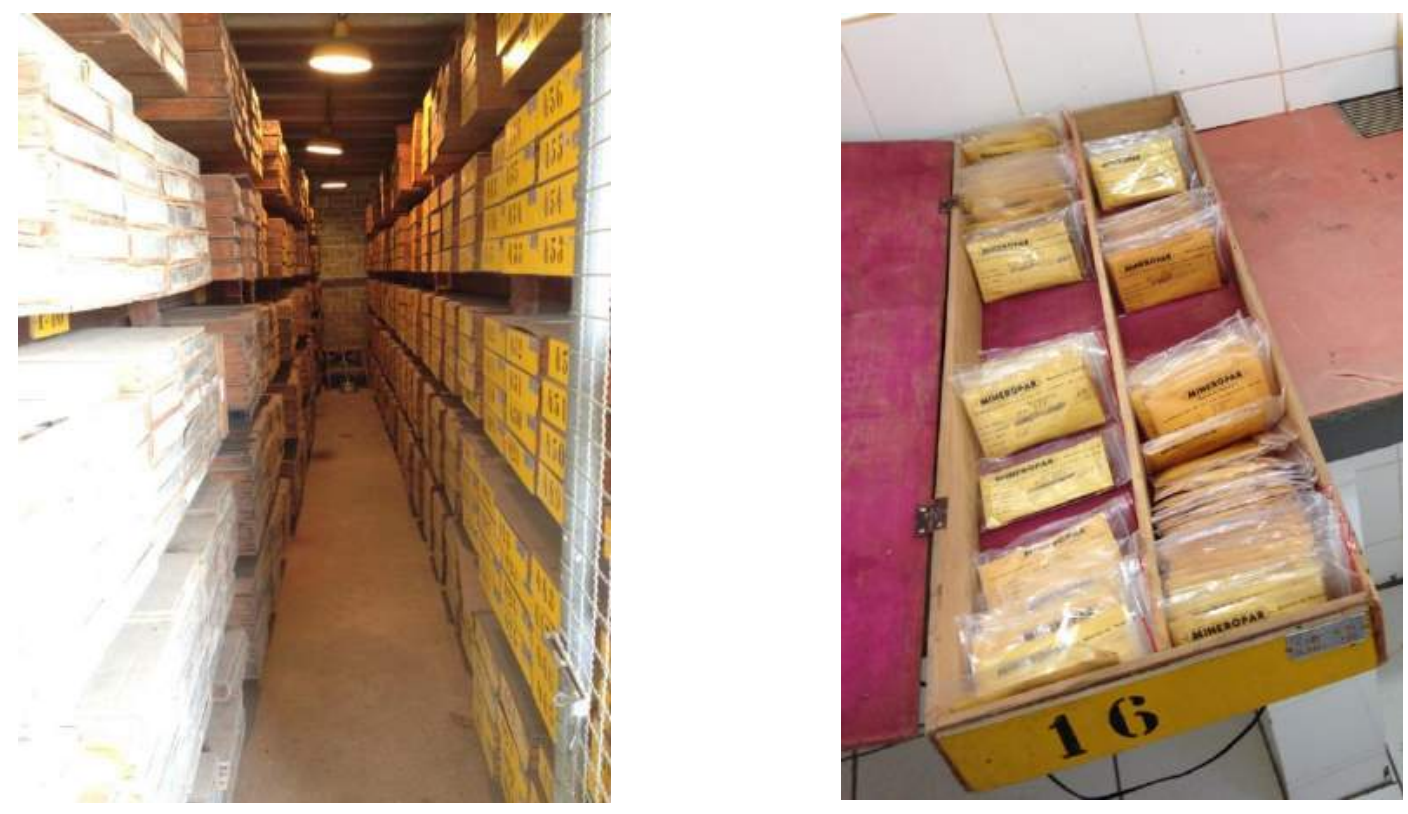

Figure 3

The Mineropar storage site of the stream sediment samples collected by old geochemical surveys (left); one box containing the envelopes into which the pulps $(<80 \#)$ of the original samples are stored, and which were used to produce the composite samples (right).

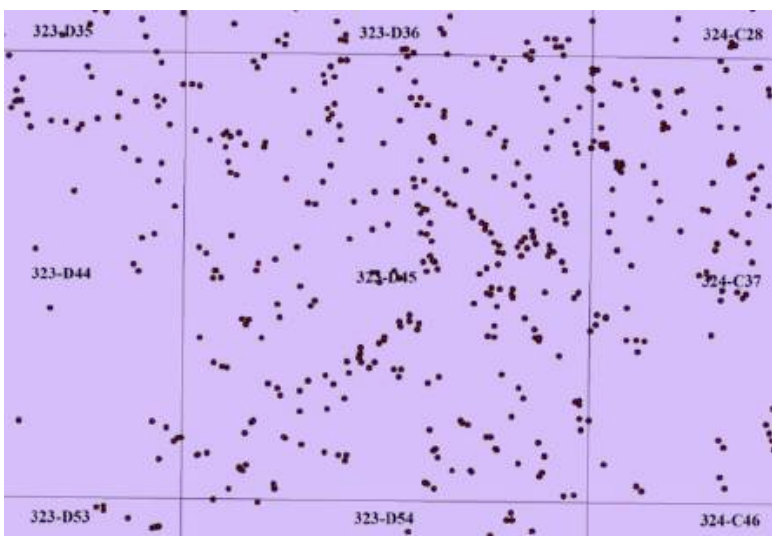

Figure 4 Position of the original stream sediment samples contained on the sub-cell 323-045.

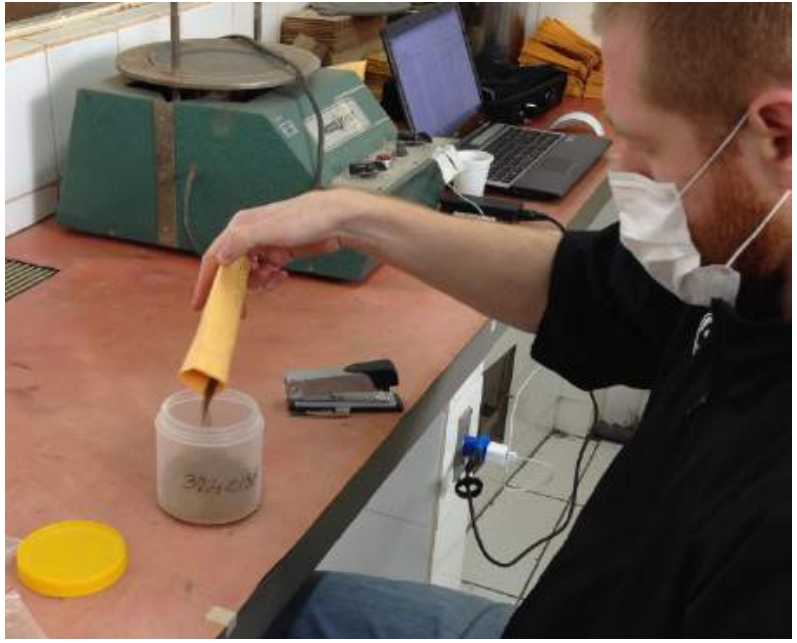

Figure 5

Preparation of composite samples by mixing together a portion of the stream sediment samples contained on each sub-cell (Mineropar laboratory).

\subsection{Analytical procedures}

All chemical analyses were made at a Brazilian commercial laboratory under contract with SGB-CPRM. There, the composite samples were sieved to $<150 \#$, and analyzed for the elements presented in Table 3. Even considering the analytical package composed by four specific techniques, combined in order to obtain the great amount of valid values as possible, some elements as $\mathrm{Ag}, \mathrm{B}, \mathrm{Pd}, \mathrm{Re}$ and

Se have had all values below the lower detection limit and were disregarded. For the other elements, except $\mathrm{Ge}$, the results below the lower detection limit were multiplied by 0.5 and those above the higher detection limit by 1.5 , as used by SGB/CPRM and MINEROPAR since the 1980's and suggested by Reimann et al. (2005). 

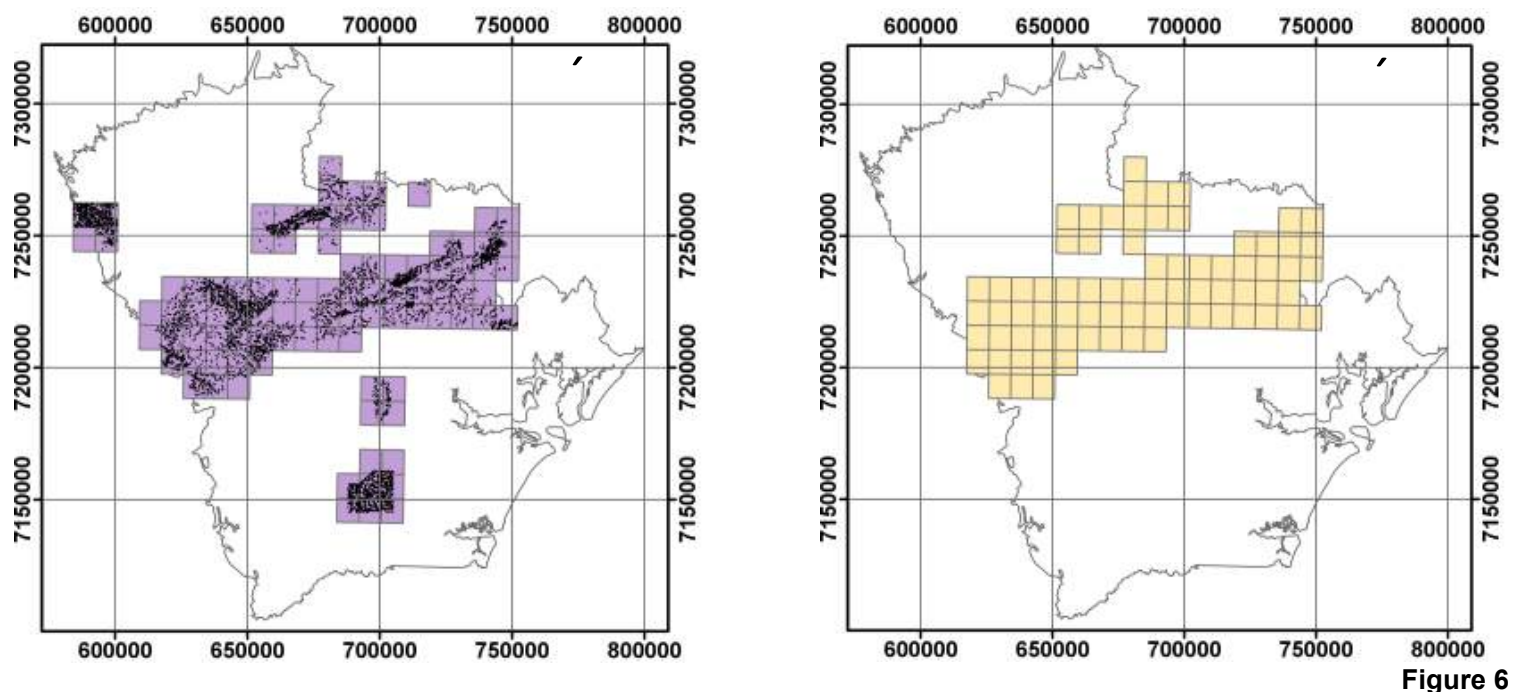

The original 9,030 stream sediments samples and the $935^{\prime} \times 5^{\prime}$ sub-cells (ca. $8 \times 8 \mathrm{~km}$ ) (left); the selected 75 sub-cells (composite samples) containing 7,428 original samples, to be used in the present article (right)

Table 3 - Summary of the analytical techniques and respective lower detection limits for each element, applied to the composite samples.

\begin{tabular}{|c|c|c|c|}
\hline $\begin{array}{c}\text { Element } \\
\text { (unit) }\end{array}$ & $\begin{array}{c}\text { Analytical } \\
\text { package }\end{array}$ & $\begin{array}{c}\text { Lower } \\
\text { Detection } \\
\text { Limit }\end{array}$ & Valid values \\
\hline $\mathrm{Al}(\%)$ & ICM14B & 0.01 & $75(100 \%)$ \\
\hline $\mathrm{Ba}(\mathrm{ppm})$ & IMS95A & 5 & $75(100 \%)$ \\
\hline $\mathrm{Be}(\mathrm{ppm})$ & IMS95A & 0.1 & $75(100 \%)$ \\
\hline $\mathrm{Bi}(\mathrm{ppm})$ & ICM14B & 0.02 & $75(100 \%)$ \\
\hline $\mathrm{Ca}(\%)$ & ICM14B & 0.01 & $75(100 \%)$ \\
\hline $\mathrm{Cd}(\mathrm{ppm})$ & ICM14B & 0.01 & $75(100 \%)$ \\
\hline $\mathrm{Ce}(\mathrm{ppm})$ & IMS95A & 0.1 & $75(100 \%)$ \\
\hline Co (ppm) & IMS95A & 0.5 & $75(100 \%)$ \\
\hline $\mathrm{Cr}(\mathrm{ppm})$ & ICM14B & 1 & $75(100 \%)$ \\
\hline Cs (ppm) & IMS95A & 0.05 & $75(100 \%)$ \\
\hline $\mathrm{Cu}(\mathrm{ppm})$ & IMS95A & 5 & $75(100 \%)$ \\
\hline Dy (ppm) & IMS95A & 0.05 & $75(100 \%)$ \\
\hline $\operatorname{Er}(\mathrm{ppm})$ & IMS95A & 0.05 & $75(100 \%)$ \\
\hline $\mathrm{Eu}(\mathrm{ppm})$ & IMS95A & 0.05 & $75(100 \%)$ \\
\hline $\mathrm{F}(\mathrm{ppm})$ & ISE03A & 30 & $75(100 \%)$ \\
\hline $\mathrm{Fe}(\%)$ & ICM14B & 0.01 & $75(100 \%)$ \\
\hline $\mathrm{Ga}(\mathrm{ppm})$ & IMS95A & 0.1 & $75(100 \%)$ \\
\hline Gd (ppm) & IMS95A & 0.05 & $75(100 \%)$ \\
\hline $\mathrm{Hf}(\mathrm{ppm})$ & IMS95A & 0.05 & $75(100 \%)$ \\
\hline $\mathrm{Hg}(\mathrm{ppm})$ & ICM14B & 0.01 & $75(100 \%)$ \\
\hline Ho (ppm) & IMS95A & 0.05 & $75(100 \%)$ \\
\hline $\mathrm{K}(\%)$ & ICM14B & 0.01 & $75(100 \%)$ \\
\hline $\mathrm{La}(\mathrm{ppm})$ & IMS95A & 0.1 & $75(100 \%)$ \\
\hline $\mathrm{Li}(\mathrm{ppm})$ & ICM14B & 1 & $75(100 \%)$ \\
\hline $\mathrm{Lu}(\mathrm{ppm})$ & IMS95A & 0.05 & $75(100 \%)$ \\
\hline $\mathrm{Mg}(\%)$ & ICM14B & 0.01 & $75(100 \%)$ \\
\hline $\mathrm{Mn}(\mathrm{ppm})$ & ICM14B & 5 & $75(100 \%)$ \\
\hline $\mathrm{Nb}(\mathrm{ppm})$ & IMS95A & 0.05 & $75(100 \%)$ \\
\hline $\mathrm{Nd}(\mathrm{ppm})$ & IMS95A & 0.1 & $75(100 \%)$ \\
\hline $\mathrm{Ni}(\mathrm{ppm})$ & IMS95A & 5 & $75(100 \%)$ \\
\hline $\mathrm{Pb}(\mathrm{ppm})$ & ICM14B & 0.2 & $75(100 \%)$ \\
\hline $\operatorname{Pr}(\mathrm{ppm})$ & IMS95A & 0.05 & $75(100 \%)$ \\
\hline $\mathrm{Rb}(\mathrm{ppm})$ & IMS95A & 0.2 & $75(100 \%)$ \\
\hline
\end{tabular}

\begin{tabular}{|c|c|c|c|}
\hline $\begin{array}{c}\text { Element } \\
\text { (unit) }\end{array}$ & $\begin{array}{l}\text { Analytical } \\
\text { package }\end{array}$ & $\begin{array}{c}\text { Lower } \\
\text { Detection } \\
\text { Limit } \\
\end{array}$ & Valid values \\
\hline Sc (ppm) & ICM14B & 0.1 & $75(100 \%)$ \\
\hline $\mathrm{Sm}(\mathrm{ppm})$ & IMS95A & 0.1 & $75(100 \%)$ \\
\hline Sn (ppm) & IMS95A & 0.3 & $75(100 \%)$ \\
\hline $\mathrm{Sr}(\mathrm{ppm})$ & IMS95A & 0.5 & $75(100 \%)$ \\
\hline $\mathrm{Tb}(\mathrm{ppm})$ & IMS95A & 0.05 & $75(100 \%)$ \\
\hline Th (ppm) & IMS95A & 0.1 & $75(100 \%)$ \\
\hline $\mathrm{Ti}(\%)$ & ICM14B & 0.01 & $75(100 \%)$ \\
\hline $\mathrm{Tl}(\mathrm{ppm})$ & ICM14B & 0.02 & $75(100 \%)$ \\
\hline $\mathrm{Tm}(\mathrm{ppm})$ & IMS95A & 0.05 & $75(100 \%)$ \\
\hline $\mathrm{U}(\mathrm{ppm})$ & IMS95A & 0.05 & $75(100 \%)$ \\
\hline $\mathrm{V}(\mathrm{ppm})$ & ICM14B & 1 & $75(100 \%)$ \\
\hline $\mathrm{Y}(\mathrm{ppm})$ & IMS95A & 0.05 & $75(100 \%)$ \\
\hline $\mathrm{Yb}(\mathrm{ppm})$ & IMS95A & 0.1 & $75(100 \%)$ \\
\hline $\mathrm{Zn}(\mathrm{ppm})$ & ICM14B & 1 & $75(100 \%)$ \\
\hline $\mathrm{Zr}(\mathrm{ppm})$ & IMS95A & 0.5 & $75(100 \%)$ \\
\hline $\mathrm{P}(\mathrm{ppm})$ & ICM14B & 50 & $74(98.67 \%)$ \\
\hline Mo (ppm) & ICM14B & 0.05 & $69(92.00 \%)$ \\
\hline In (ppm) & ICM14B & 0.02 & $67(89.33 \%)$ \\
\hline $\mathrm{Sb}(\mathrm{ppm})$ & ICM14B & 0.05 & $66(88.00 \%)$ \\
\hline S (\%) & ICM14B & 0.01 & $58(77.33 \%)$ \\
\hline $\mathrm{Ta}(\mathrm{ppm})$ & IMS95A & 0.05 & $56(74.76 \%)$ \\
\hline $\mathrm{W}(\mathrm{ppm})$ & IMS95A & 0.1 & $55(73.33 \%)$ \\
\hline As (ppm) & ICM14B & 1 & $50(66.67 \%)$ \\
\hline $\mathrm{Na}(\%)$ & ICM14B & 0.01 & $39(52.00 \%)$ \\
\hline $\mathrm{Pt}(\mathrm{ppb})$ & FAI515 & 5 & $19(25.33 \%)$ \\
\hline Te (ppm) & ICM14B & 0.05 & $19(25.33 \%)$ \\
\hline $\mathrm{Au}(\mathrm{ppb})$ & FAI515 & 5 & $13(17.33 \%)$ \\
\hline $\mathrm{Ge}(\mathrm{ppm})$ & ICM14B & 0.1 & $2(2.67 \%)$ \\
\hline $\mathrm{Pd}(\mathrm{ppb})$ & FAI515 & 5 & $0(0 \%)$ \\
\hline $\operatorname{Re}(p p m)$ & ICM14B & 0.1 & $0(0 \%)$ \\
\hline $\mathrm{Se}(\mathrm{ppm})$ & ICM14B & 1 & $0(0 \%)$ \\
\hline $\mathrm{Ag}(\mathrm{ppm})$ & ICM14B & 0.01 & $0(0 \%)$ \\
\hline $\mathrm{B}(\mathrm{ppm})$ & ICM14B & 110 & $0(0 \%)$ \\
\hline
\end{tabular}

Key for the analytical techniques: ICM14B = Aqua regia digestion + ICP-MS; IMS95A $=\mathrm{LiBO}_{2}$ fusion + ICP-MS; ISE03A

$=$ Alkaline fusion, dissolution and determination by Specific Ion Electrode; FAI515 = fire assay + ICP-OES. 


\subsection{QUALITY CONTROL}

The analyses of the 75 composite samples were monitored by the internal quality control of the contracted laboratory, which comprises the use of analytical blanks, duplicate and certified standard samples. Furthermore, the analyses of original vs. composite samples, and also composite vs. duplicate samples were evaluated. To verify the analytical reprodu-

\subsection{STATISTICAL DATA TREATMENT}

The results were submitted to statistical analyses to obtain either univariate or bivariate information. The classical and robust statistical estimates for each of the variables were calculated: minimum value, first quartile, median, mean, third quartile and maximum value as well the percentiles not only to evaluate the statistical behavior of the variables (Appendix 2), but also as a support to the construction of the geochemical maps.

The authors are aware that a geochemical database with such complexity would be a very adequate dataset to the application of a statistical approach of Compositional Data (CoDa). Nonetheless, a conventional statistical treatment was adopted, which is supported by

\subsubsection{BIVARIATE CORRELATION PROCEDURES}

The Pearson correlation coefficient (r) is an usual technique to measure the similarity of behavior between pairs of variables. To be considered valid, a correlation coefficient should be checked against significance tables containing the critical values for the correlation coefficients, considering the degrees of freedom of each pair of variables (number of pairs -2 ) and a probability level, either 0.05 or 0.01. Otherwise, the Spearman rank correlation, is more applicable to highly skewed data sets, since it is not linear and thus not affected by the presence of outliers. To be

\subsubsection{GEOCHEMICAL MAPPING}

Due to the large dimension of the sub-cells (ca. $8 \mathrm{~km}$ side) the geochemical maps showing the cells classified by its elemental content display a rough aspect of a matrix of pixels (Figure 7).

In order to produce better structured geochemical maps with smoothest contours, it was applied the minimum curvature interpolation method, with an unitary isotropic cibility and also to test the homogeneity of the composite samples, portions of eight randomly selected composite samples $(323-\mathrm{D} / 45,323-$ $\mathrm{D} / 51,323-\mathrm{D} / 63$, 324-C/05, 324-C/34, 324$\mathrm{C} / 40,324-\mathrm{D} / 11$ and $324-\mathrm{D} / 38$ ) were sent to the laboratory as a new sample, thus composing a replicate sample.

the following observation by Reinmann et al. (2012): "... the very aim of a regional geochemical mapping project is to study and predict the distribution (concentration) of a chemical element in two-dimensional space. Such maps have been successfully used to aid geological mapping, for mineral exploration, for documenting contamination, and for detecting a multitude of additional processes that determine the distribution of chemical elements at the Earth's surface. It will be hard to convince a regional geochemist that all these maps are "wrong" and that dimensionless ratio maps (which ratio?) are the only correct maps."

statistically valid under these premises, a correlation coefficient should be higher than the critical index found in the table. The validated correlation coefficients are thus highlighted on the correlation matrix to be correctly considered on further analysis.

Correlation diagrams are useful tools to graphically synthesize a correlation matrix (KRUMBEIN; GRAYBILL 1965 APUD SINCLAIR; BLACKWELL 2006). They were drawn using only positive correlation coefficients higher than 0.65 , and using the application EZCorrGraph (CAMPOS 2018).

search radius, maximum residual value of 1.5 , 100,000 maximum interactions and an unitary relaxation value (SURFER 2002). In order to restrict the interpolated maps to the limits of the studied area, a geographic filter (polygon mask) was applied to cut out the outer subcells. So, the elemental contents become represented by isograd curves (isovalues), highlighting the geochemical structures. 

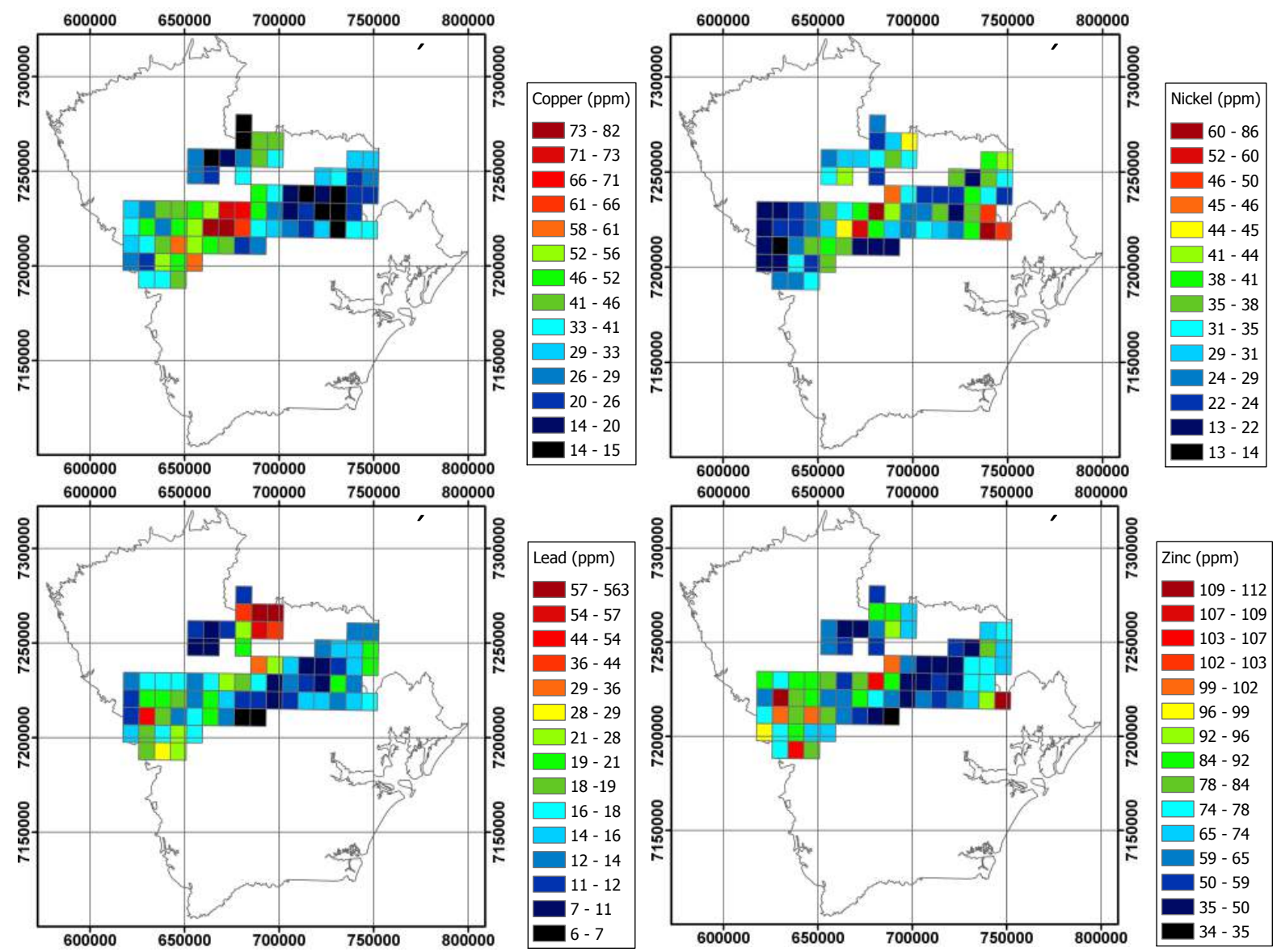

Geochemical maps showing the 75 sub-cells classified (raster style) by its $\mathrm{Cu}$ (upper left), $\mathrm{Ni}$ (upper right), $\mathrm{Pb}$ (lower left) and $\mathrm{Zn}$ (lower right) contents in the stream sediment composite samples.

\subsubsection{NUMERIC-CHROMATIC SCALE USED ON THE GEOCHEMICAL MAPS}

To better distinguish and also to enhance those areas with higher concentration in the geochemical map and attenuating the lower ones, was adopted a scale composed by selected percentile, i.e., $5,15,25,40,50,65$, $75,85,90,91,93,95,97,98$, along the lowest and maximum values of the chosen element. Weaver et al. (1983), Bølviken et al. (1986) and Björklund and Gustavsson (1987), justify the usage of this scale also to minimize outlier's influence.

To compose a numerical value expressing the association of element obtained from the correlation analysis (see item 3.5), the content of the elements must be converted to a common measure scale, since each element has a specific unit and range of measure. The standard unit or Z score (Formula 1) reduces all variables to a similar and dimensionless measure scale, preserving their distribution curves and statistical behavior.

$$
z_{i}=\frac{x_{i}-\bar{x}}{s} \quad \text { Formula } 1
$$

Thus, the associations of elements will become expressed as the algebraic grand sum of the standard unit of each element, which compose a specific association, as exemplified by the Formula 2.

Association $2=z_{B a}+z_{N a}+z_{S r}$ Formula 2 


\section{RESULTS}

\subsection{CONTENTS IN THE ORIGINAL VS. COMPOSITE SAMPLES}

When comparing the contents of the same element in both data sets - original and composite samples - different magnitudes of measure were obtained. There are two main reasons to explain this discrepancy: (1) sample density: the original samples contained in each cell represent small catchment basins and the composite samples represent a mix of all them, thus the lowest and highest contents in each cell, as well as the highest standard deviations, will appear on the analyses of the original samples; (b) analytical procedures: the original samples were sieved to $<80 \#$ fraction and digested with concentrate and hot $\mathrm{HNO}_{3}$; the elements were determined by atomic absorption spectrometry. On the other hand, the composite samples, which were constituted by small portions of $<80 \#$ pulps, were sieved again to $<150 \#$, digested by aqua regia and then analysed by ICP-MS. Thus it is clear that the analytical procedure applied on the composite samples was able to release a higher amount of the elements, which will reflect on higher values for the $1^{\text {st }}$ quartile, median, average and $3^{\text {rd }}$ quartile.

The differences in the statistic estimates for the same elements in both set of samples are shown in Table 4.

Table 4 - Summary of the statistical estimates comparing the element contents on the original samples and on the composite samples

\begin{tabular}{|c|c|c|c|c|c|c|c|c|c|}
\hline Element & $\begin{array}{l}\text { Type of } \\
\text { sample }\end{array}$ & $\mathrm{N}$ & $\begin{array}{l}\text { Lowest } \\
\text { content }\end{array}$ & $\begin{array}{c}1^{\text {st }} \\
\text { quartile }\end{array}$ & Median & Average & $\begin{array}{c}3^{\text {rd }} \\
\text { quartile }\end{array}$ & $\begin{array}{l}\text { Highest } \\
\text { content }\end{array}$ & $\begin{array}{l}\text { Standard } \\
\text { Deviation }\end{array}$ \\
\hline \multirow{2}{*}{$\begin{array}{c}\text { As } \\
(\mathrm{ppm})\end{array}$} & Original & 4,170 & 0.05 & 1 & 2 & 3.28 & 4 & 186 & 6.0652 \\
\hline & Composite & 75 & 0.55 & 0.55 & 2 & 4.477 & 5.5 & 34 & 6.3677 \\
\hline \multirow{2}{*}{$\begin{array}{c}\text { Co } \\
(\mathrm{ppm})\end{array}$} & Original & 4,971 & 1 & 10 & 16 & 18.68 & 24 & 121 & 12.1554 \\
\hline & Composite & 75 & 8.2 & 14.65 & 18.1 & 18.92 & 21.95 & 35.7 & 6.3811 \\
\hline \multirow{2}{*}{$\begin{array}{c}\mathrm{Cu} \\
(\mathrm{ppm})\end{array}$} & Original & 6,876 & 1 & 10 & 18 & 23.13 & 29 & 700 & 23.1453 \\
\hline & Composite & 75 & 14 & 25.5 & 33 & 36.72 & 46 & 82 & 15.2958 \\
\hline \multirow{2}{*}{$\begin{array}{c}\mathrm{F} \\
(\mathrm{ppm})\end{array}$} & Original & 1,093 & 73 & 349 & 564 & 645.73 & 830 & 8,450 & 556.9180 \\
\hline & Composite & 75 & 91 & 187 & 262 & 345.1 & 360.5 & 5,308 & 594.1555 \\
\hline \multirow{2}{*}{$\begin{array}{l}\mathrm{Fe} \\
(\%)\end{array}$} & Original & 1,833 & 0.05 & 1.5 & 2.4 & 2.79 & 3.4 & 15 & 1.9049 \\
\hline & Composite & 75 & 1.68 & 3.495 & 4.37 & 4.457 & 5.315 & 8.84 & 1.4626 \\
\hline \multirow{2}{*}{$\begin{array}{c}\mathrm{Mn} \\
(\mathrm{ppm})\end{array}$} & Original & 5,254 & 10 & 390 & 700 & 1340.33 & 1500 & 55,000 & 2080.2110 \\
\hline & Composite & 75 & 346 & 693.5 & 1053 & 1365 & 1676 & 4403 & 920.3308 \\
\hline \multirow{2}{*}{$\begin{array}{c}\mathrm{Ni} \\
(\mathrm{ppm})\end{array}$} & Original & 4,519 & 1 & 11 & 16 & 19.46 & 24 & 251 & 14.3580 \\
\hline & Composite & 75 & 13 & 24 & 31 & 32.43 & 38 & 86 & 11.5854 \\
\hline \multirow{2}{*}{$\begin{array}{c}\mathrm{Pb} \\
(\mathrm{ppm})\end{array}$} & Original & 7,428 & 1 & 12 & 16 & 22.46 & 22 & 12,000 & 145.3671 \\
\hline & Composite & 75 & 6.9 & 11.85 & 15.6 & 25.11 & 19.45 & 563 & 63.7022 \\
\hline \multirow{2}{*}{$\begin{array}{c}\mathrm{Zn} \\
(\mathrm{ppm})\end{array}$} & Original & 6,816 & 1 & 41 & 61 & 68.12 & 85 & 1,300 & 44.6322 \\
\hline & Composite & 75 & 34 & 59 & 74 & 71.35 & 84 & 112 & 19.3959 \\
\hline
\end{tabular}

\subsection{COMPOSITE SAMPLES - ORIGINAL VS. REPLICATE ANALYSIS}

Ideally, the results obtained from the original and its replicate sample, should have equal values, so in the quality control charts a line with a slope of $45^{\circ}$ in relation to the abscissa would be generated. However, due to natural sample heterogeneity and the steps of homogenization and splitting in the Jones riffle splitter during the process of producing composite samples, this ideal scenario does not occur, and for some elements the analytical error surpassed $\pm 10 \%$. Since an error of $\pm 10 \%$ between original and duplicate analysis is generally acceptable for the exploration geochemistry purposes (THOMPSON; HOWARTH 1973, 1976a, 1976b), the quality control charts were established considering a channel of $\pm 10 \%$ centered in the $45^{\circ}$ line. For almost all elements with errors worse than $\pm 10 \%$, the major discrepancies are found in the region of lowest contents, a very common situation in analytical databases. On the other hand, for some elements such as Sn and W, whose dispersion is based on the clastic form producing a random and almost high analytical variability, an error worse than $\pm 10 \%$ is comprehensible and acceptable (Table 5). 
Table 5 - Reproducibility of analytical results on the quality control pairs of composite samples (original vs replicate) Better than $\pm \mathbf{1 0} \%$ (all samples inside the confidence channel)

As, Be, Ca, Ce,

$\mathrm{Co}, \mathrm{Cr}, \mathrm{Cs}, \mathrm{Eu}, \mathrm{Gd}$, Ge, $\mathrm{Mg}, \mathrm{Pb}, \mathrm{Pt}, \mathrm{Sr}$, Th, V

\section{Lower contents \\ $\mathrm{Al}$ (1), Ba (2), Bi (2), \\ Cd (2), Cu (1), Dy (1), \\ $\mathrm{Er}(1), \mathrm{Fe}(1), \mathrm{F}(4), \mathrm{Ga}(1), \mathrm{Hf}$ \\ (3), Hg (2), Ho (2),}

In (3), K (1), La (1), Li (4), Lu

(1), Mn (1), Mo (4),

$\mathrm{Na}(1), \mathrm{Nb}(2), \mathrm{Nd}(1)$,

$\mathrm{Ni}$ (3), P (2), Pr (1), Rb (1), S

(2), Sb (2), Sc (2), Sm (1), Sr

(1), Tb (2), Ti (1),

Tm (2), U (1), Y (1), Yb (1), $\mathrm{Zn}(1), \mathrm{Zr}$ (4)

$$
\text { Zn (1), Zr (4) }
$$

Worse than $\pm 10 \%$

Higher content

Randomly distributed

Au (1), In (1), Lu (1),

Mo (1), Na (1), P (1),

$\mathrm{S}$ (1), Te (2), Tl (1)

Tm (1), Y(1), Yb (1)
Sn (8), Ta (7), W (5)

Note: the figure between parenthesis is the number of pairs falling out the confidence channel of $\pm 10 \%$

From the Table 6 it becomes clear that quality control pairs 6 and 7, are those which concentrate the analytical error for several elements. This seems to indicate that the composite samples should be produced with more than four homogenization steps on the Jones riffle splitter. Some representative cases of quality control charts are shown in Figure 8.

Table 6 - Elements out of the $\pm 10 \%$ confidence channel in each quality control pair (original vs. replicate composite sample)

\begin{tabular}{|c|c|}
\hline $\begin{array}{l}\text { Quality control pair } \\
\text { (composite sample code) }\end{array}$ & Elements \\
\hline $1(323-\mathrm{D} / 45)$ & F, Hf, Hg, La, Mo, P, Sn, Sr, Ta, W, Zr \\
\hline $2(324-\mathrm{C} / 05)$ & $\mathrm{Al}, \mathrm{Au}, \mathrm{In}, \mathrm{K}, \mathrm{Li}, \mathrm{Mo}, \mathrm{Ni}, \mathrm{S}, \mathrm{Sn}, \mathrm{Ta}, \mathrm{Te}, \mathrm{Zr}$ \\
\hline $3(324-\mathrm{D} / 11)$ & In, $\mathrm{Na}, \mathrm{Nb}, \mathrm{S}, \mathrm{Sb}, \mathrm{Sn}, \mathrm{Ta}, \mathrm{Tm}, \mathrm{W}$ \\
\hline $4(324-\mathrm{C} / 40)$ & $\mathrm{In}, \mathrm{Na}, \mathrm{P}, \mathrm{Sn}, \mathrm{Ta}, \mathrm{W}, \mathrm{Zr}$ \\
\hline $5(323-\mathrm{D} / 63)$ & $\mathrm{Cd}, \mathrm{Li}, \mathrm{Mo}, \mathrm{Ni}, \mathrm{P}, \mathrm{Sn}, \mathrm{Ta}$ \\
\hline $6(324-C / 34)$ & $\begin{array}{l}\mathrm{Ba}, \mathrm{Bi}, \mathrm{Cu}, \mathrm{Cd}, \mathrm{Dy}, \mathrm{Er}, \mathrm{F}, \mathrm{Fe}, \mathrm{Hf}, \mathrm{Ho}, \mathrm{Li}, \mathrm{Lu}, \mathrm{Mn}, \mathrm{Mo}, \mathrm{Nb}, \mathrm{S}, \mathrm{Sc}, \mathrm{Sn}, \mathrm{Tb}, \mathrm{Ti}, \mathrm{Tl}, \mathrm{Tm}, \\
\mathrm{W}, \mathrm{Y}, \mathrm{Yb}, \mathrm{Zn}, \mathrm{Zr}\end{array}$ \\
\hline $7(323-\mathrm{D} / 51)$ & $\begin{array}{l}\text { Ba, Bi, Er, F, Ga, Hf, Ho, In, Lu, Mo, Nd, Ni, Pr, Rb, Sb, Sc, Sm, Sn, Ta, Tb, Te, Tm, } \\
\text { U, Y, Yb, W }\end{array}$ \\
\hline $8(324-\mathrm{D} / 38)$ & $\mathrm{F}, \mathrm{Hg}, \mathrm{Li}, \mathrm{Sn}, \mathrm{Ta}$ \\
\hline
\end{tabular}

\subsection{COMPARISON BETWEEN ORIGINAL VS. COMPOSITE SAMPLES}

The concentration of the elements determined in the composite samples were compared to the mean and to the median concentration of the original samples contained in the respective cells (see Appendix 1). This comparison could only be made for As, Co, $\mathrm{Cu}, \mathrm{F}, \mathrm{Fe}, \mathrm{Mn}, \mathrm{Ni}, \mathrm{Pb}$ and $\mathrm{Zn}$, which compose the former geochemical database (LICHT; TARVAINEN 1996). As emphasized before (item 3.1), it is necessary to take into account that this correlation analysis was performed between contents obtained with two different analytical techniques in the original and in the composite samples.

Table 7 - Correlation coefficient $(r)$ between the contents of the composite samples and the median and the average of contents of the original samples contained in the same cell.

\begin{tabular}{|c|c|c|c|c|c|c|c|c|c|}
\hline & As & Co & $\mathrm{Cu}$ & $\mathbf{F}$ & $\mathrm{Fe}$ & Mn & $\mathbf{N i}$ & $\mathbf{P b}$ & $\mathbf{Z n}$ \\
\hline Median & 0,75 & 0,79 & 0,88 & 0,16 & 0,81 & 0,78 & 0,55 & 0,27 & 0,47 \\
\hline Average & 0,64 & 0,72 & 0,86 & 0,49 & 0,81 & 0,88 & 0,59 & 0,99 & 0,62 \\
\hline
\end{tabular}

Notes: $\mathrm{N}=75$, degrees of freedom $=73$; critical $\mathrm{r}_{0.01}=0.31$. Correlation coefficient lower than the critical $\mathrm{r}$, are underscored.

From the correlation coefficient (Table 7) and also from the correlation graphs (Figures 9 to 11), it becomes clear that, apart from As, Co and $\mathrm{Cu}$, the concentrations of the composite samples behave much more similarly to the average value of the original samples contained in the respective sub-cell than to it median. 

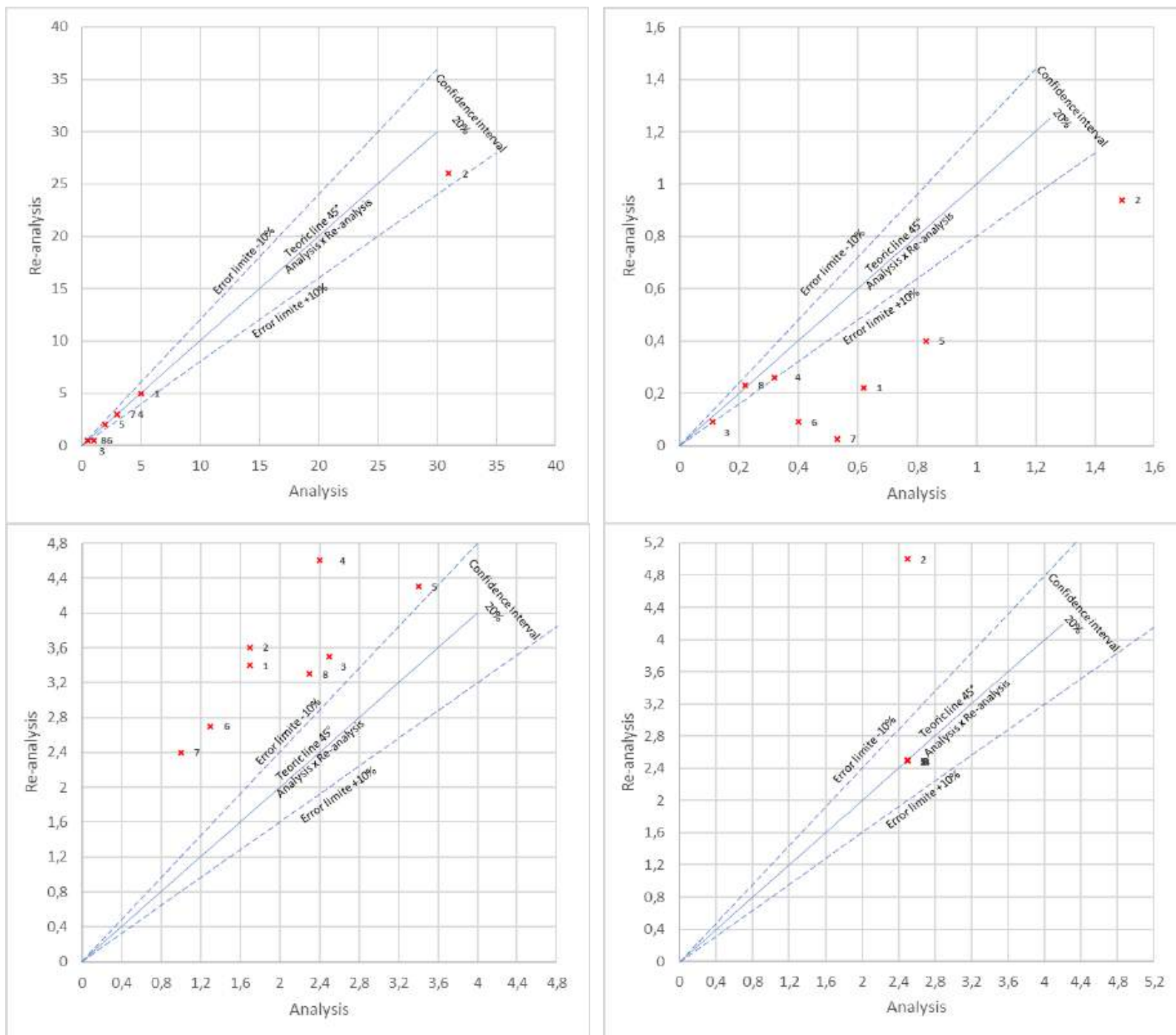

Composite samples vs. duplicates. Quality control charts of selected elements: As (upper left), Mo (upper right), Au (lower left) and Sn (lower right)
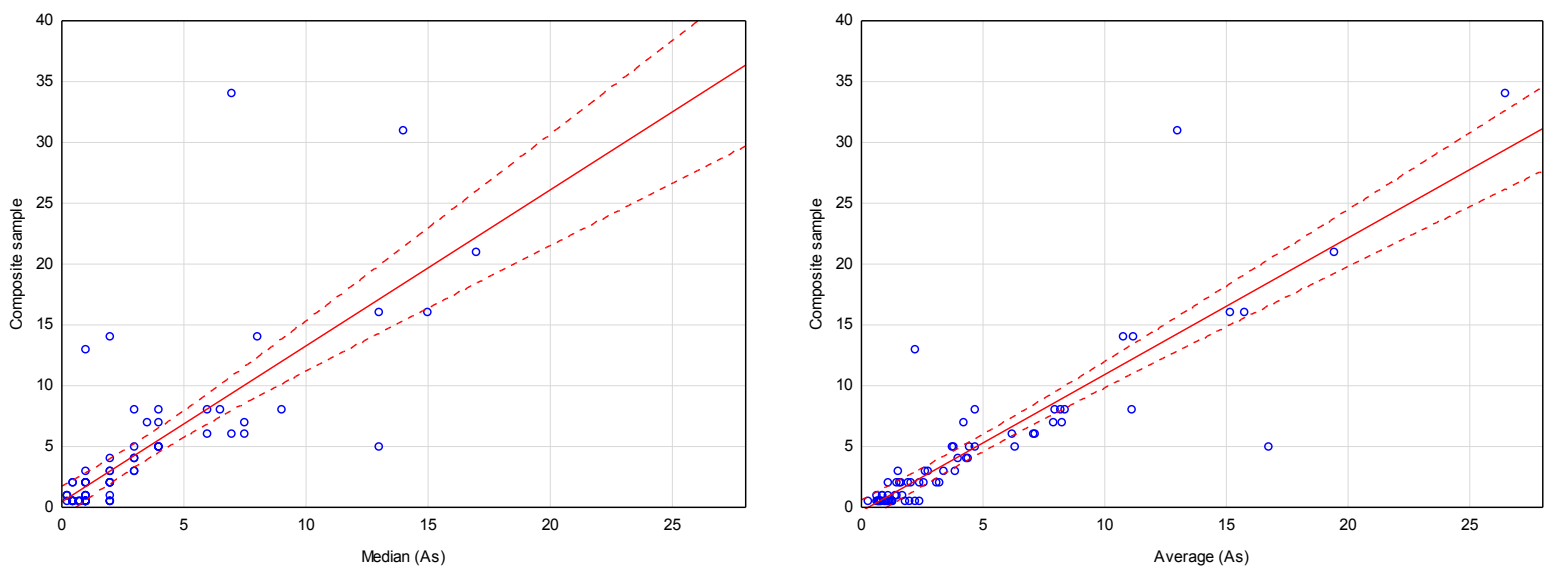

Figure 9

Correlation graph for As (ppm) content in the composite samples vs the median of the original samples $(r=0.75)$ (left) and the average of the original samples $(r=0.64)$ (right). The confidence channel represents the significance level of 0.05 . 

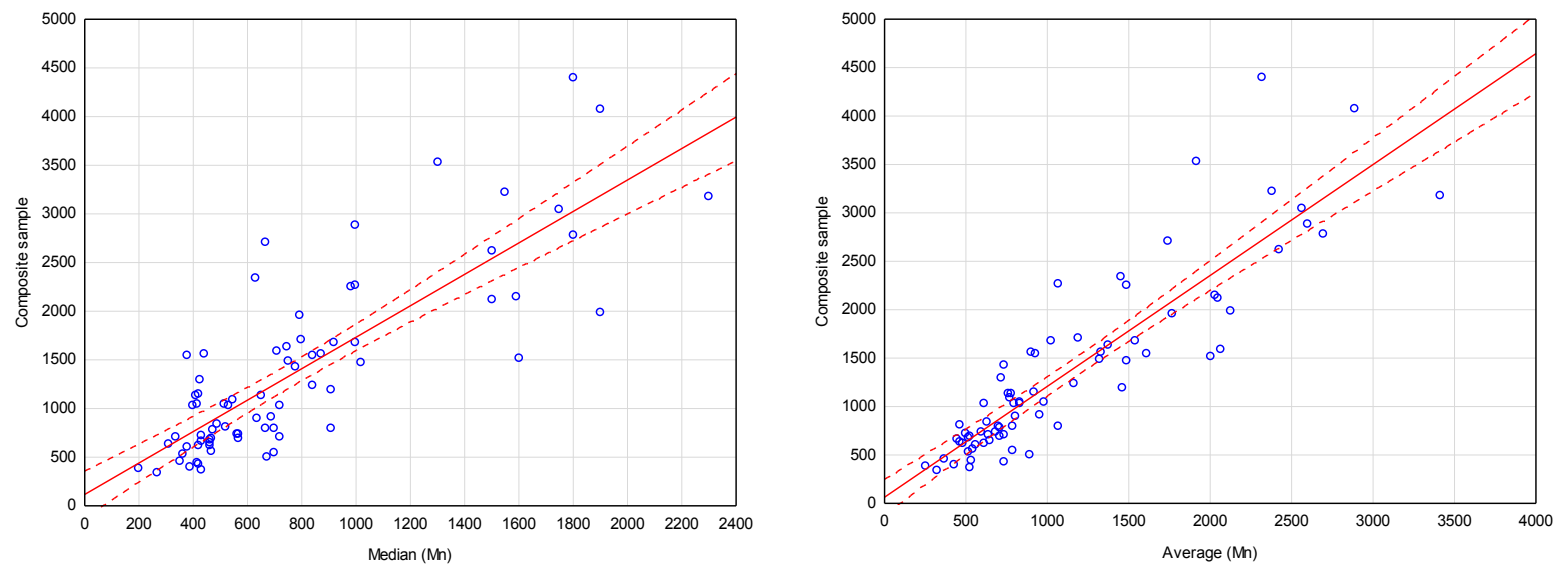

Figure 10

Correlation graph for $\mathrm{Mn}(\mathrm{ppm})$ content in the composite samples vs the median of the original samples $(r=0.78)$ (left) and the average of the original samples $(r=0.88)$ (right). The confidence channel represents the significance level of 0.05
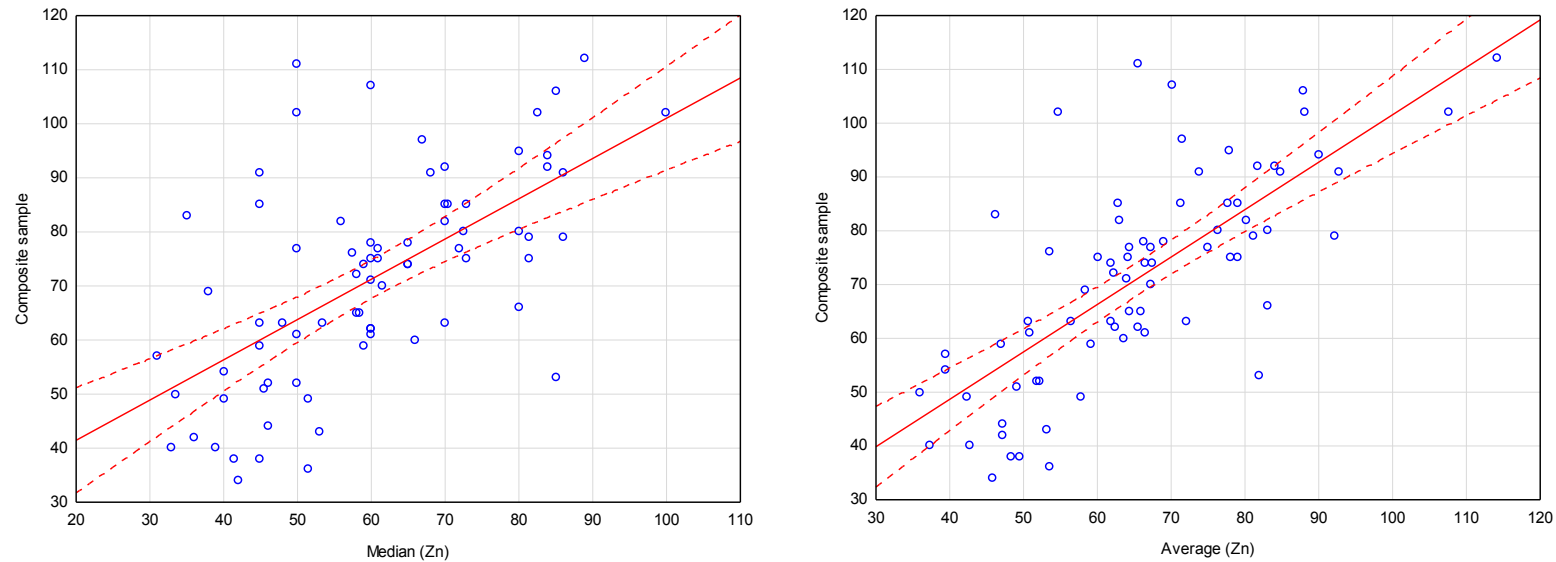

Figure 11

Correlation graph for the $\mathrm{Zn}(\mathrm{ppm})$ content in the composite samples vs the median of the original samples $(r=0.47)$ (left) and the average of the original samples $(r=0.62)$ (right). The confidence channel represents the significance level of 0.05 .

It is possible to explain this fact making a parallel with some statistical concepts. For a data set which contains outlier values, they will display an important role on the calculation of the average, increasing its value, but will display a minor importance in the calculation of the median, reducing its value. Following this line of thought, it is clear that original samples with outlier contents were included and influenced the composite samples increasing its content, which made the final content of the composite sample more similar to the average than to the median.

Thus, except for $\mathrm{As}, \mathrm{Co}$ and $\mathrm{Cu}$, the angle of the correlation lines for the means of the original samples vs. the contents of the composite samples are closer to $45^{\circ}$, the confidence channels become narrower and the correlation indexes are higher. All of these indicators are evidence for similar behaviors.

On the other hand, two single cases of nonsignificant correlation indices, i.e., less than critical $r$, are those of the median of $F$ and of $\mathrm{Pb}$.

With these results it can be stated that except for three exceptions (As, $\mathrm{Co}$ and $\mathrm{Cu}$ ), for the data set here considered, the content of the composite samples works as the arithmetic mean of the contents of the original samples of the respective cell.

\subsection{GEOCHEMICAL MAPPING OF THE FORMER VS. THE NEW GEOCHEMICAL DATABASES}

When the general arrangement of the geochemical structures in the maps produced with the contents of composite samples are compared to those produced with the mean contents of the original samples (Figure 12 to Figure 20), it is surprising that maps drawn with such different datasets are so similar. 

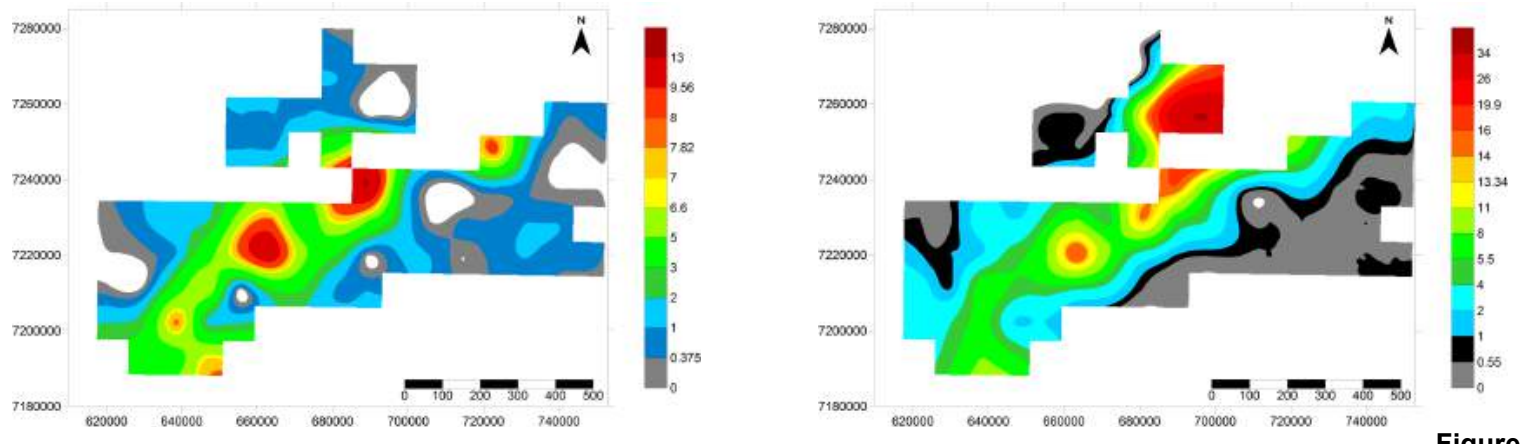

Figure 12

Arsenic (ppm) in stream sediments: 6,587 original samples (left) and 75 composite samples (right)
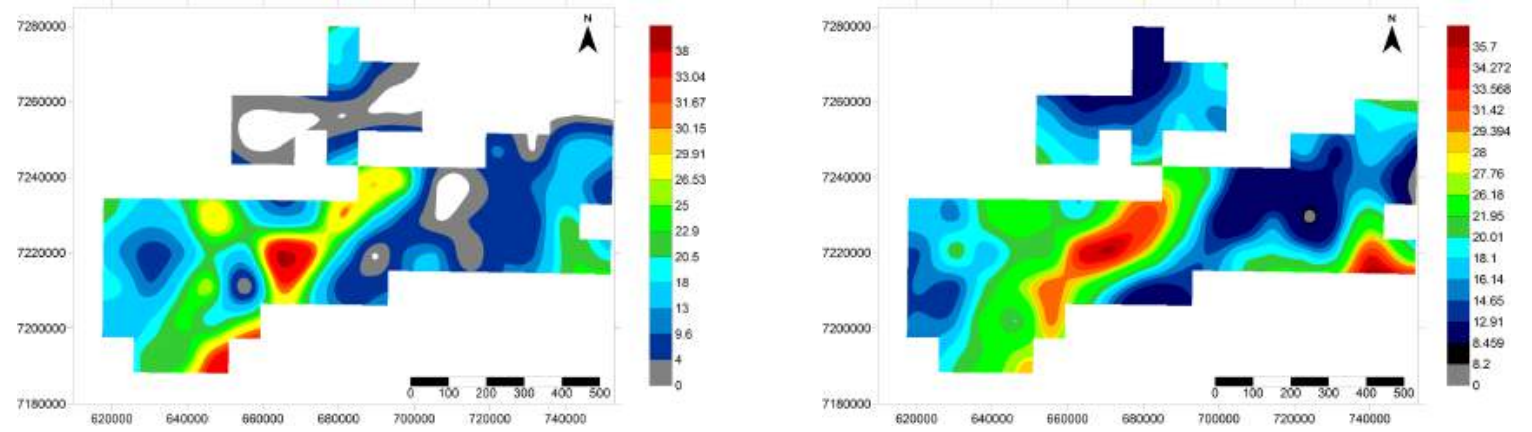

Figure 13

Cobalt (ppm) in stream sediments: 6,587 original samples (left) and 75 composite samples (right)
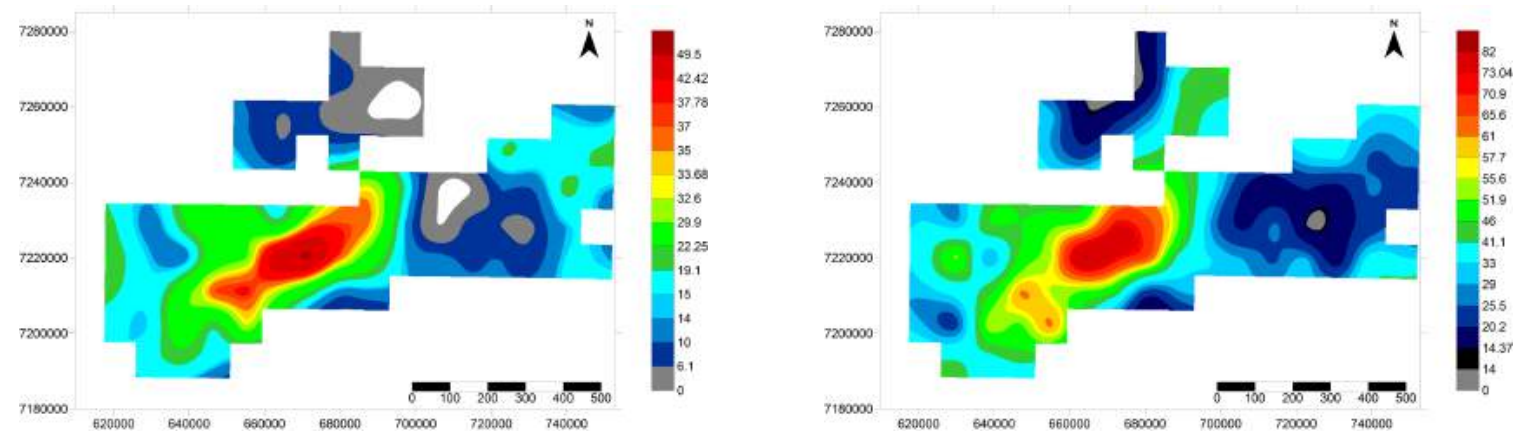

Figure 14

Copper (ppm) in stream sediments: 6,587 original samples (left) and 75 composite samples (right)
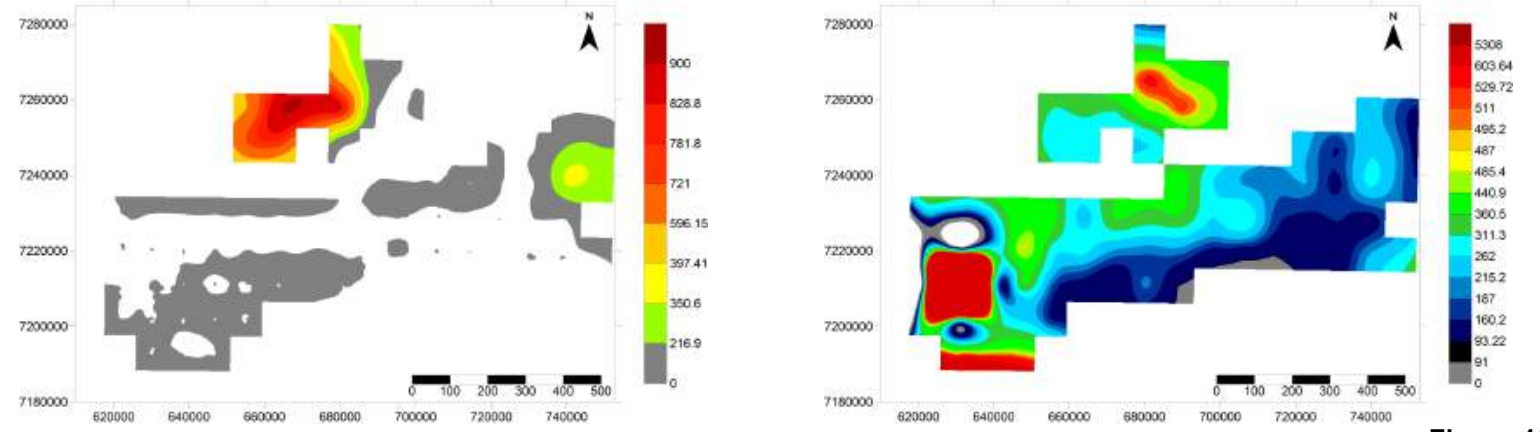

Fluorine (ppm) in stream sediments: 6,587 original samples (left) and 75 composite samples (right). Only few, and very geographically concentrated, original samples were analyzed for $F$ and the resulting map (left) became incomplete and shows a strange display. 

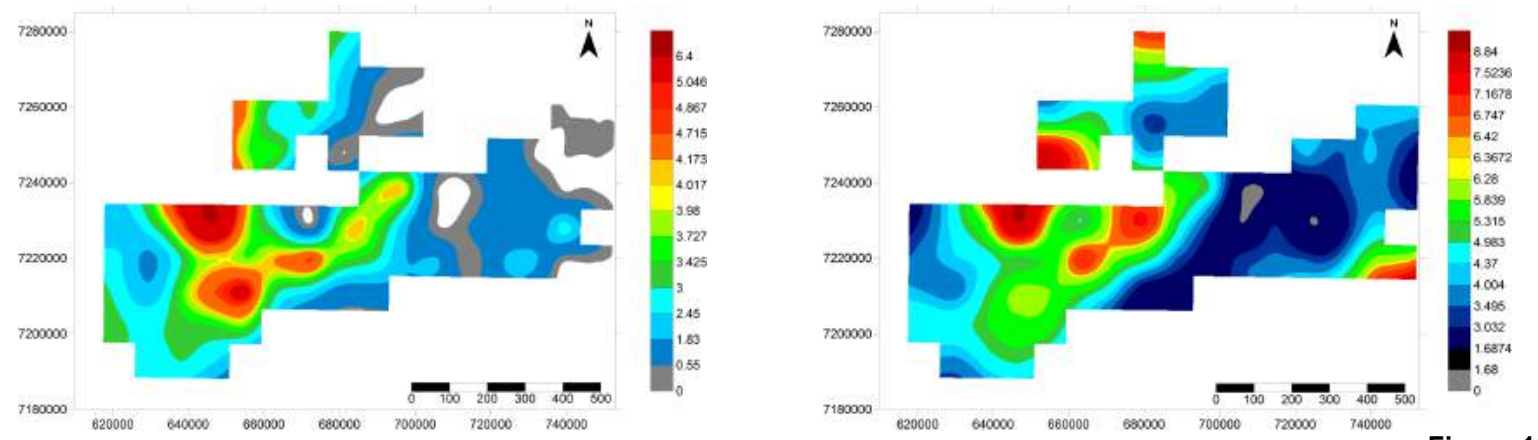

Iron (ppm) in stream sediments: 6,587 original samples (left) and 75 composite samples (right)
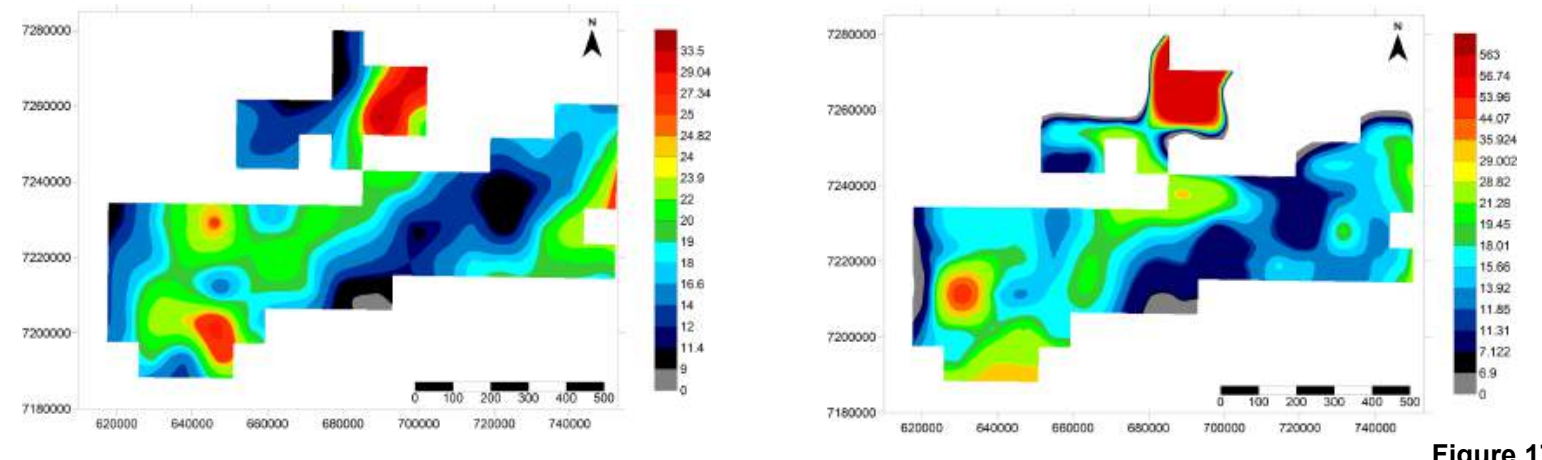

Lead (ppm) in stream sediments: 6,587 original samples (left) and 75 composite samples (right)
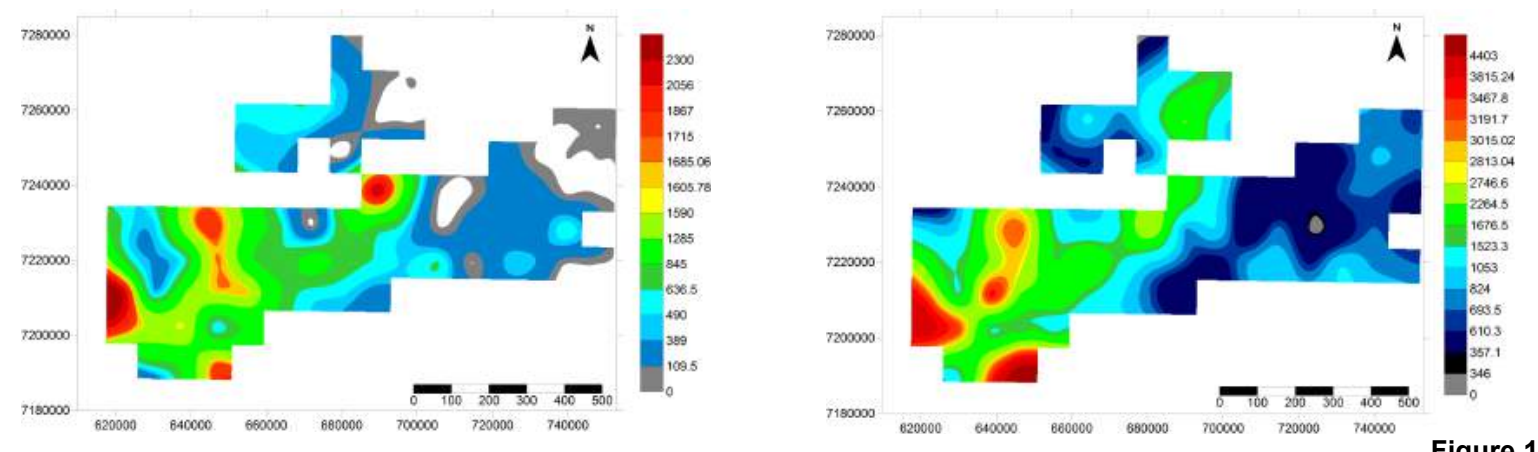

Manganese (ppm) in stream sediments: 6,587 original samples (left) and 75 composite samples (right)
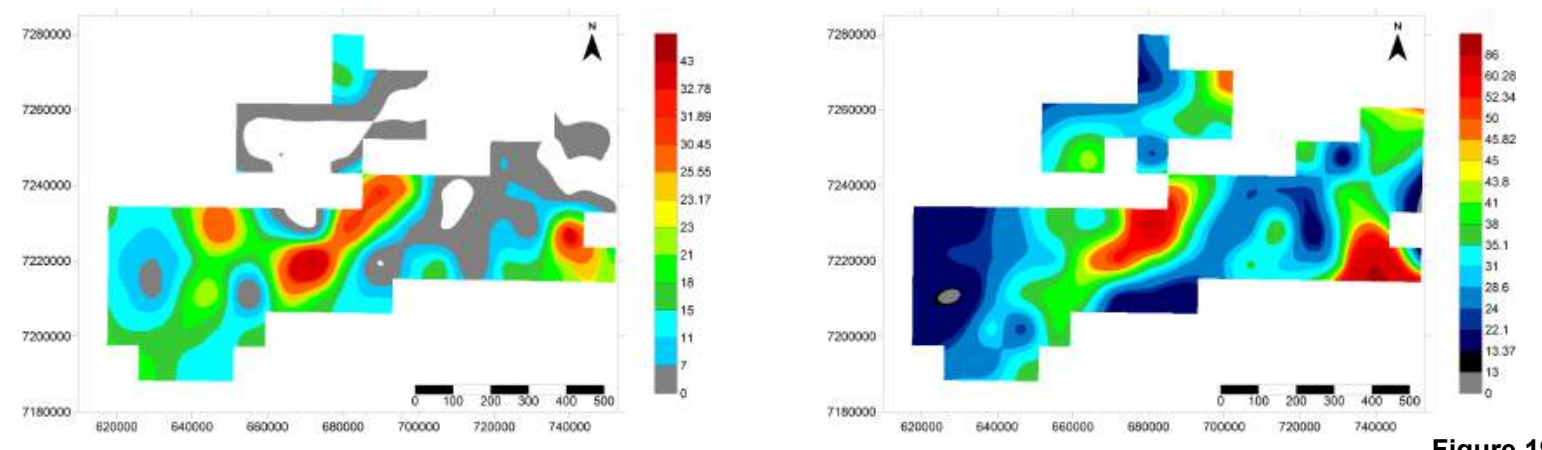

Nickel (ppm) in stream sediments: 6,587 original samples (left) and 75 composite samples (iight) 

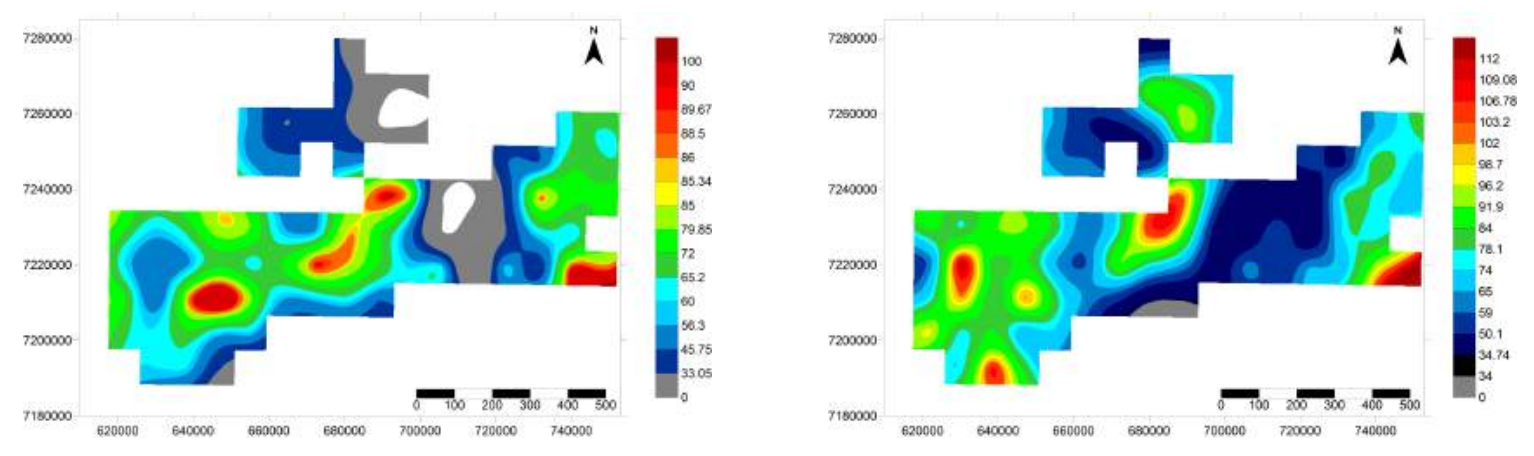

Zinc (ppm) in stream sediments: 6,587 original samples (left) and 75 composite samples (right)

As it can be seen on Figures 12 to 20, the geochemical maps showing the distribution of the results of composite samples lost some detail and spatial resolution. However, it is also possible to observe the clear concordance between the main geochemical structures shown in both maps for each element. This fact was expected and has been reported by Fordyce et al. (1993) and Darnley et al. (1995). These authors state that the geochemical patterns follow a fractal pattern, in which forms are similar and reproduce themselves regardless the observation scale.

\subsection{STATISTICAL BEHAVIOR AND DISTRIBUTION OF THE ELEMENTS}

The studied area is represented by a very complex geological background (item 1.1), thus a statistical appraisal of the multi-element database produced by the geochemical analysis of the composite samples is presented only as a reference (Appendix 2).

Almost all the histograms are clearly lognormal, showing a strong and positive asymmetry, with the median positioned in the first three class intervals. Some elements like $\mathrm{Co}$ and $\mathrm{Cu}$ are uni-modal, others like $\mathrm{Cr}$, Dy and $\mathrm{Er}$ are bi-modal and still others are polymodal like $\mathrm{Ca}, \mathrm{Cd}, \mathrm{Ce}$ and Eu.

Such modal variations express the heterogeneity of the chemical composition of the samples, which in turn reflect the complexity of the geological background of the study area.

\subsection{BI-VARIATE CORRELATION ANALYSES AND ASSOCIATION OF ELEMENTS}

Using the Pearson linear correlation technique, only those pairs of variables with correlation coefficients higher than the critical value of $0.575(\alpha=0.01)$ were retained. The exception is $\mathrm{Au}$, whose critical value is 0.684 . Due to the large number of variables, to draw the correlation diagrams, it was necessary to adopt a cut-off value for the correlation coefficient, thus being considered only the pairs of elements with $r \geq 0.65$.

The correlation diagrams constructed from these selected pairs have grouped 49 elements into seven associations that are presented in Figure 21 and summarized in Table 8.

All pairs in which $\mathrm{Al}, \mathrm{Au}, \mathrm{Ca}, \mathrm{Cr}, \mathrm{Ga}, \mathrm{Ge}$, $\mathrm{Hg}, \mathrm{In}, \mathrm{Li}, \mathrm{Nb}, \mathrm{Pt}, \mathrm{S}, \mathrm{Sn}, \mathrm{Sr}, \mathrm{Te}, \mathrm{Tl}$ and $\mathrm{W}$ participate, had correlation coefficient lower than 0.65 , thus these elements were not included in any of the seven associations.
The maps showing the distribution of these geochemical associations (Figure 22 to 27) were drawn with the algebraic grand sum of the standard unit $\left(\mathrm{Z}_{\mathrm{i}}\right)$ of the elements composing each association.

It is important to note that the main direction of the geological and structural framework of the researched region are well delineated in the maps of the elemental associations, since all show main geochemical trends according to NE-SW.

The application of Spearman rank correlation was not so effective in separating associations of chemical elements, and for this reason only the results from the Pearson correlation was considered to establish the element associations, in the geochemical mapping and in the correlation with the geological background. 

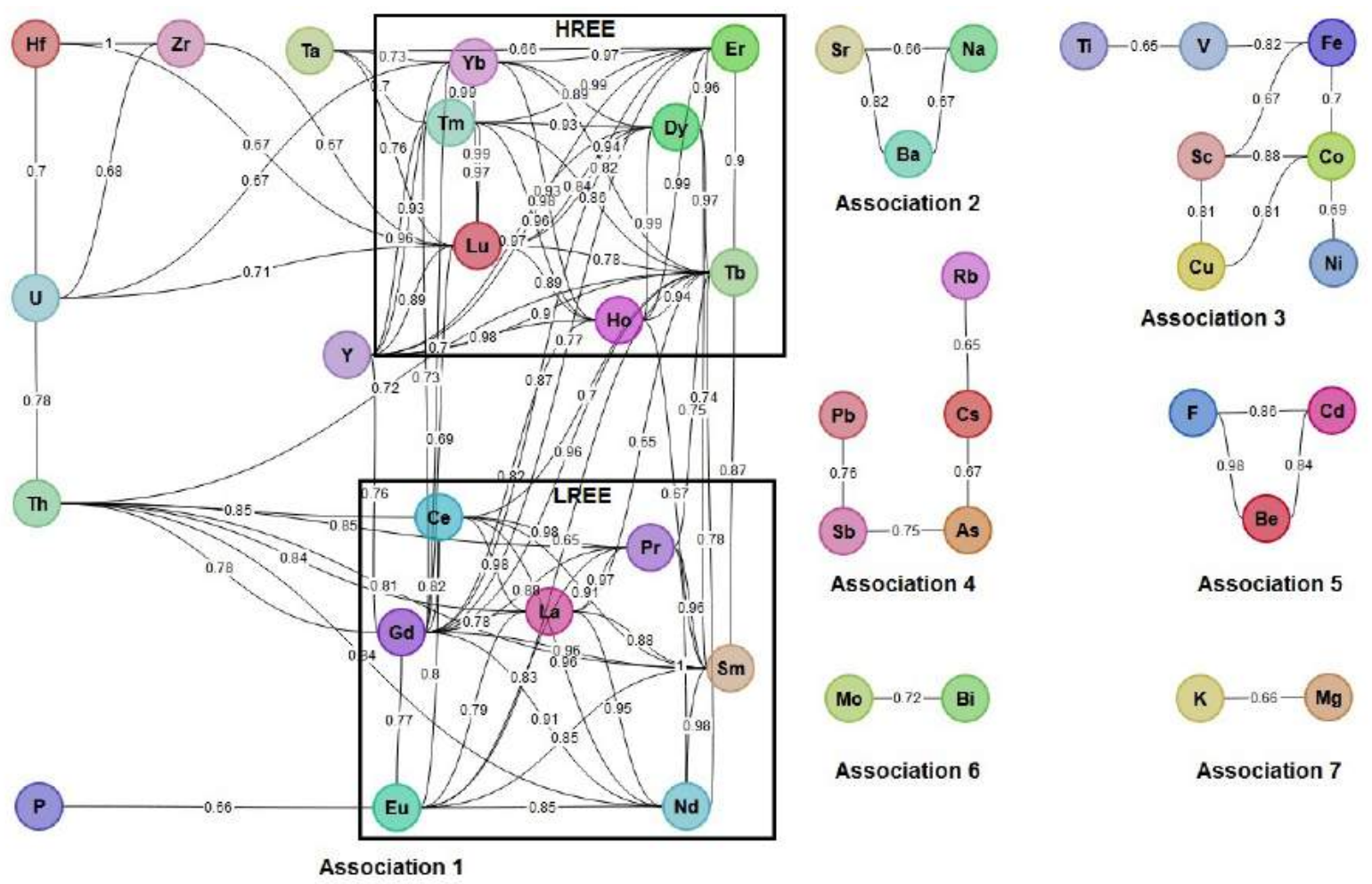

Association 4

Association 5
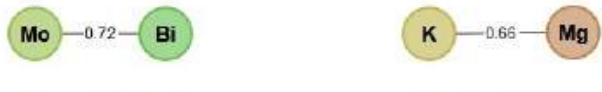

Association 6

Association 7

Figure 21 Correlation diagrams showing the seven associations of elements produced by bi-variate correlation analysis in the stream sediment composite samples (see Table 8).

Table 8 - Summary of the associations of elements produced by bi-variate correlation analysis in the stream sediment composite samples (see Figure 21).

\begin{tabular}{cc}
\hline Association & Elements \\
\hline 1 & Hf-Zr-U-Ta-Y-Tb-Dy-Ho-Er-Tm-Yb-Lu-Th-La-Ce-Pr-Nd-Sm-Eu-Gd-(P) \\
\hline 2 & Ba-Na-Sr \\
\hline 3 & Fe-Sc-Co-Cu-Ni-Ti-V \\
\hline 5 & As-Cs-Sb-Pb-Rb \\
\hline 6 & Cd-Be-F \\
\hline 7 & Bi-Mo \\
\hline
\end{tabular}

\subsection{GEOCHEMICAL ASSOCIATIONS AND GEOLOGICAL BACKGROUND - A CAUSE-EFFECT RELATIONSHIP}

The geological inheritance is clearly presented in all maps either for the isolated elements or for their associations. We attribute this main relationship to the fact that the original stream sediment samples were collected in the 1970s and 1980s, when human occupation in the studied area was still incipient. Examples of human influence on geochemical survey data in part of this researched area are found in Licht (2018).
Association 1 - related to the granitic bodies of Alto Turvo, Graciosa, Rio Salto, Banhado and Morro Grande. The lowest values predominate in the meta sedimentary rocks which belongs to the Açungui Group and over the Três Córregos Granite (Figure 22).

Association 2 - emphasizes the northern portion of the Três Córregos Granite. The lower values predominate in the Açungui Group meta-sedimentary rocks (Figure 23). 


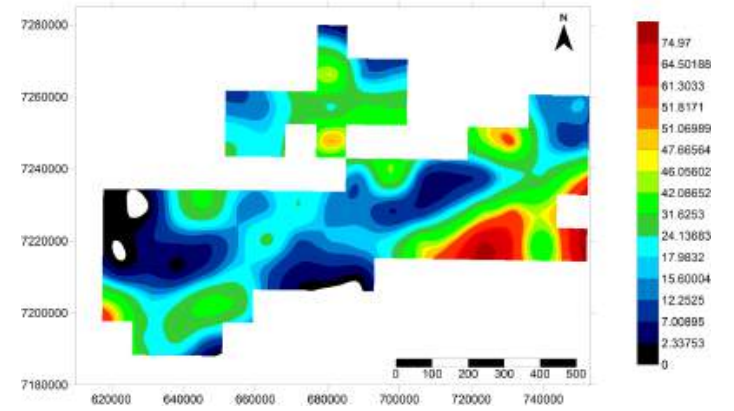

Figure 22

Geochemical map of the association 1

Both associations 1 and 2 reflect the presence of granitic intrusions, but are also strongly influenced by intrusions of alkaline bodies, some associated with carbonatites as is the case of that known as 'Barra do Itapirapuã'.

Association 3 - mostly associated to the Votuverava Formation, which belongs to the Açungui Group. The lowest values, apparently

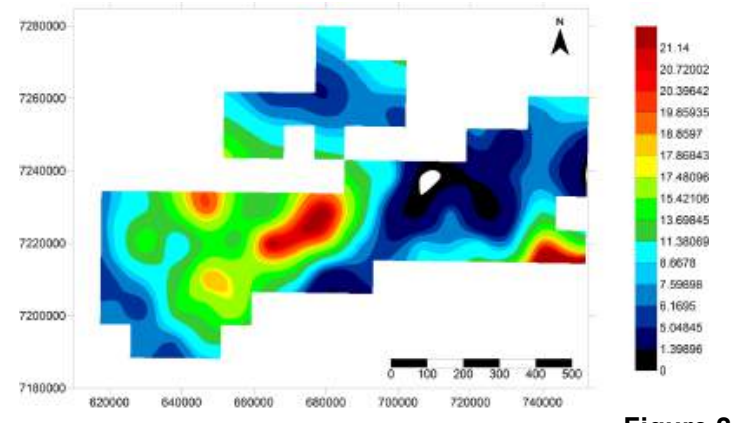

Geochemical map of the association 3

Association 5 - mark those cells where meta-sedimentary rocks of the Votuverava Formation predominate. In this region, some fluorspar occurrences are known, being the active $\mathrm{F}$ mine in the Mato Preto carbonatite the most important. In addition to $\mathrm{F}, \mathrm{W}$ is associated to the Nagib Silva and Areia Branca granites. Its lowest values predominate on the Gneiss-migmatite Complex. In the south-

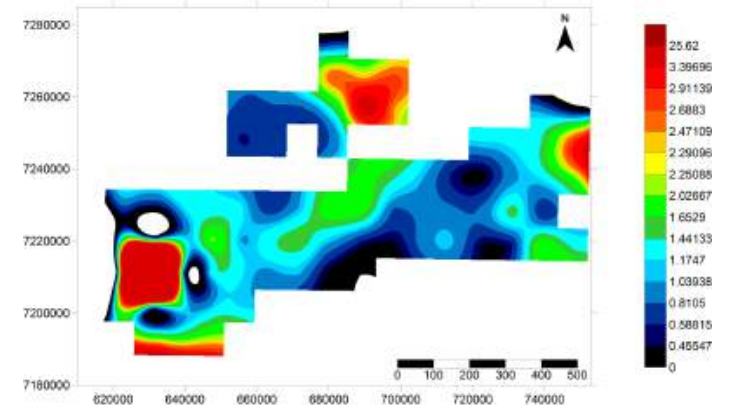

Geochemical map of the association 5

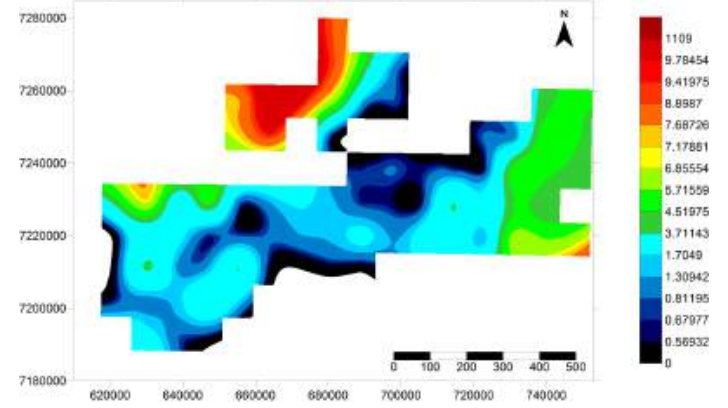

Figure 23

Geochemical map of association 2

coincides with the transcurrent Lancinha Fault zone (Figure 24).

Association 4 - has a similar behavior to Association 3 and fits to the Votuverava Formation, but there is a geographic coincidence between the main $\mathrm{Pb}$ occurrences and mines located in the Ribeira river valley and the highest values of the Association 4. The lowest values occur mainly over the Três Córregos Granite (Figure 25).

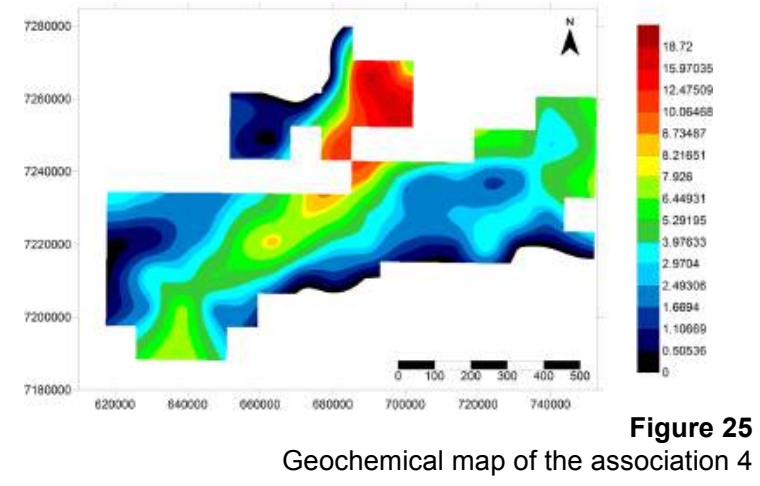

western border, an extremely high value for this association is related to southern portion of the Três Córregos granite (Figure 26).

Association 6 - has high values in the cells to the north, but especially in that cell located on the Banhado Granite. As occur with association 5 , the lowest values predominate in the gneiss-migmatite complex (Figure 27).

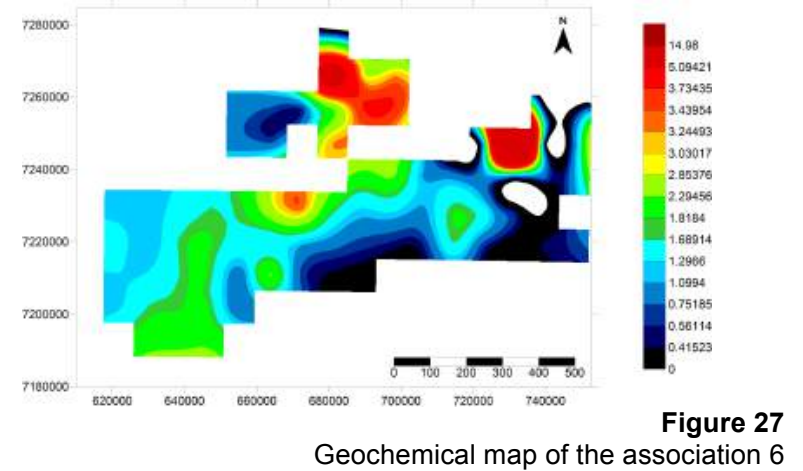


Association 7 - based on the available geological knowledge, the authors do not reach

\subsection{FAVORABILITY TO MINERAL EXPLORATION}

An extremely valuable result of this research was to point-out a special location, geographically coincident to southern portion of the Três Córregos Granite. This is the case of the sub-cell 323-D / 52 which shows high values of the Association 5 (Figure 26) followed by some indicator and pathfinder elements, e.g, $\mathrm{Au}, \mathrm{Cd}, \mathrm{Tl}$ and $\mathrm{Hg}$ (Figure 28)

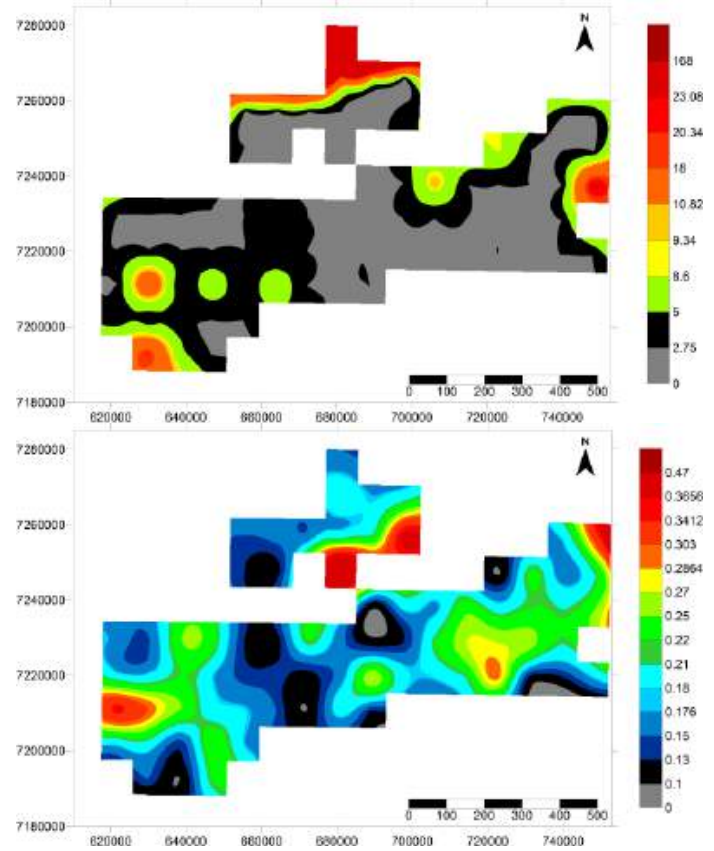

any causal relationship for the Association 7 composed by $\mathrm{K}-\mathrm{Mg}$ in the studied area. as well as F (Figure 15), which do not participate in any of the associations.

The database of mineral occurrences does not indicates any mineral showing which would justify this multielement geochemical anomaly. Therefore, this sub-cell constitutes an area of great potential and favorability for mineral exploration of $\mathrm{Au}, \mathrm{F}$ and other associated elements mentioned above.

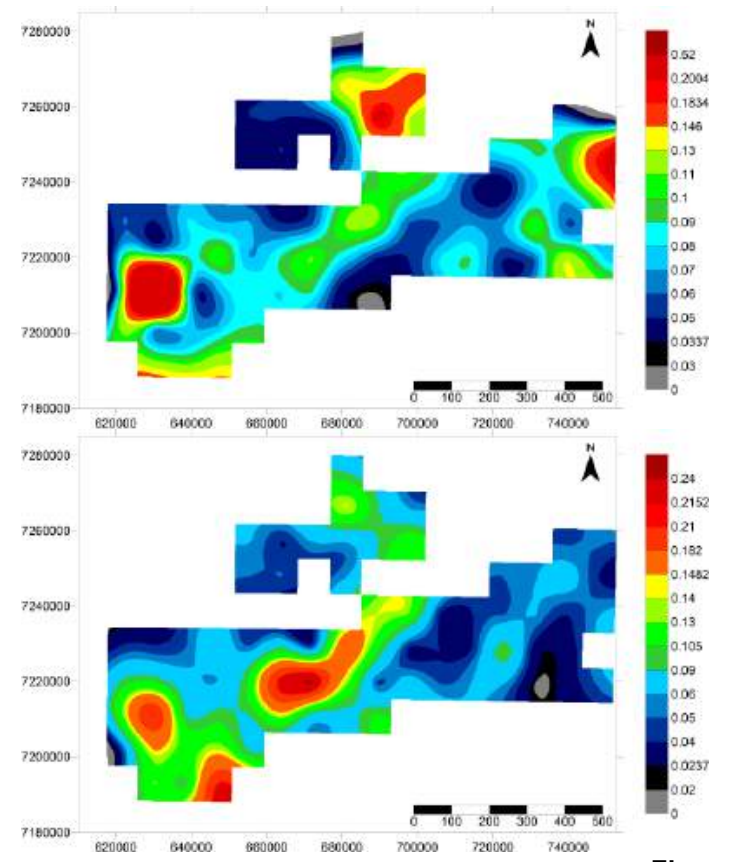

Figure 28

Geochemical map of $\mathrm{Au}$ (ppb) (upper left), Cd (pm) (upper right), TI (ppm) (lower left) and $\mathrm{Hg}$ (ppm) (lower right) in the 75 stream sediments composite samples. In the western border of the studied area and in all of these maps a geochemical high is clearly marked, corresponding to the southern portion of the Três Córregos Granite.

The follow-up of this mineral exploration target could be easily made, by retrieving the original samples from the sample storage site and sending it to be analyzed by the same analytical techniques. The Figure 28 shows the original stream sediments sampling sites displayed over the hydrographic network of the sub-cell 323-D / 52 and the geologic background. Some sampling sites are slightly displaced from the hydrographic network because they were collected in the 1980's when aerial photos were the main technique for orientation in the field, causing some errors in the coordinates attributed to the samples. 


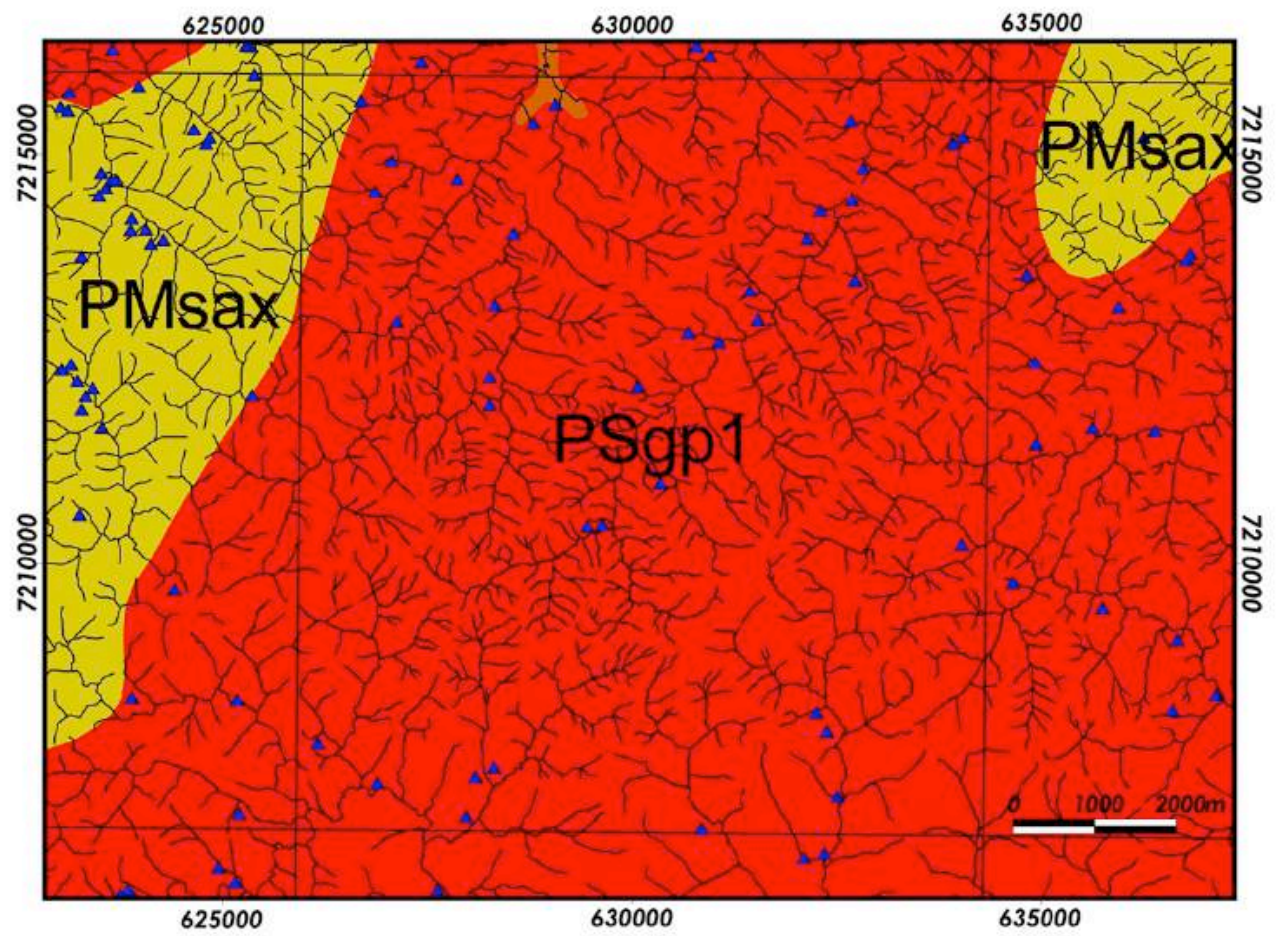

Figure 28

The sub-cell 323-D / 52, which shows anomalous values of the Association 5 along with some indicator and pathfinder elements, e.g, Au, Cd, Tl, $\mathrm{Hg}$ and F. The stream sediment original samples (blue triangles) are plotted along the hydrographic network. Key: PSgp1 = Três Córregos granite, Pmsax = Agua Clara Formation, Setuva Group.

\section{CONCLUSIONS}

Composite samples representing a regular cell grid which has been composed from old stream sediment samples adequately stored constitute an useful and low cost technique to quickly evaluate large areas with no additional field costs. At a relatively low cost, these composite samples may be submitted to multielement analysis, producing reliable geochemical maps and revealing new geochemical structures and associations of elements, some of them pointing to unknown exploratory targets.

From the elements which has been directly compared (As, $\mathrm{Co}, \mathrm{Cu}, \mathrm{F}, \mathrm{Fe}, \mathrm{Mn}, \mathrm{Ni}, \mathrm{Pb}$ and $\mathrm{Zn})$ the present research showed that the contents of the composite samples are statistically valid and equivalent to the arithmetic mean of the previous analytical results of the original samples used to composed it.

Even in this area, which was already submitted to many previous mineral

\section{ACKNOWLEDGEMENTS}

The authors acknowledge the Board of the Serviço Geológico do Paraná (State of Paraná Geological Survey) MINEROPAR, and exploration surveys, the procedure of retrieval stream sediment samples collected by old surveys and analyzing them by modern analytical techniques was able to delineate a very interesting geochemical target, located on the southern portion of the Três Córregos Granite.

The usage of modern data processing procedures and statistical approaches such as Compositional Data (CoDa) and Geostatistics, on such multielement database, may enable more advanced interpretations with great economy of financial resources.

Lastly, the authors believe that one of the most important contributions of the present research is to proof the viability of the application of this cell grid technique based on composite stream sediments samples in other Brazilian regions and even other countries, which have large sample storage facilities representing large and relatively unexplored regions.
Serviço Geológico do Brasil (Brazil Geological Survey) SGB/CPRM by welcoming the idea, understanding the purpose and the 
scope of this research, and for the financial support. We thank the Laboratório de Análise de Minerais e Rochas (LAMIR/UFPR) for providing analytical facilities to homogenize and split samples. The authors thank to the reviewer Timo Tarvainen (Geological Survey

\section{REFERENCES}

BJÖRKLUND A., GUSTAVSSON N. 1987. Visualization of geochemical data on maps: new options. Journal of Geochemical Exploration, v. 29, n. 1-3, p. 89-103.

BØLVIKEN B., BERGSTROM J., BJÖRKLUND A., KONTIO M., LEHMUSPELTO P., LINDHOLM T., MAGNUSSON J., OTTESEN R.T., STEENFELT A., VOLDEN T. 1986. Geochemical atlas of Northern Fennoscandia. Copenhagen : Geological Survey of Sweden : Geological Survey of Finland : Geological Survey of Norway.

CAMPOS, F.F. 2018. EZCorrgraphH. Available on https:/ezcorrgraph.firebaseapp.com/

CRISIGIOVANNI, F.L. 2016. Geoquímica multielementar de sedimentos fluviais ativos da porção Centro-oeste do Precambriano Paranaense: uma abordagem baseada em amostras compostas em malha regular. Curitiba, Programa de Pós Graduação em Geologia, Universidade Federal do Paraná. 195p.

DARNLEY A.G., BJÖRKLUND A., BØLVIKEN B., GUSTAVSSON N., KOVAL P.V., PLANT, J.A., STEENFELT A., TAUCHID M., XUEJING X. 1995. A Global Geochemical Database for Environmental and Resource Management: Recommendations for International Geochemical Mapping. Final Report of IGCP Project 259. UNESCO Publishing, Paris, p.122.

FIORI, A.P., CAMARGO, E.C., MONASTIER, M.S., LIMA, R.E. DE., FUMAGALLI, C.E., SALAMUNI, E., FASSBINDER, E., GÓIS, J.R. 1984 Lineamentos tectônicos e possíveis mineralizações associadas no pré-Cambriano paranaense. Curitiba : MINEROPAR : UFPR, v. 1. Convênio UFPR-MINEROPAR.

FIORI, A.P. 1985 As falhas da Lancinha e de morro Agudo e estruturas secundárias asssociadas. In : SIMPÓSIO SUL-BRASILEIRO DE GEOLOGIA (2 :1985 : Florianópolis). Anais... Florianópolis : SBG. p. 146-158.

FORDYCE F.M., GREEN P.M., SIMPSON P.R. 1993. Simulation of regional geochemical survey maps at variable sample density. Journal of Geochemical Exploration v. 49 161-175.

LICHT, O.A.B. 2018. Multiscale, multimedia and multielementar geochemical mapping of the State of Paraná, Brazil. Geochimica Brasiliensis 32(2): 209 - 242, of Finland - Geologian Tutkimuskeskus) for his useful criticisms and suggestions to improve this article. We also thank Daiane Höffig (University of Texas) for the suggestions to the language improvement in the early version of the article.

LICHT O.A.B., TARVAINEN T. 1996 Multipurpose geochemical maps produced by integration of geochemical exploration data sets in the Paraná Shield, Brazil. Journal of Geochemical Exploration, v. 56, p.167-182.

MINEROPAR 2006. Mapa geológico do Estado do Paraná. Scale 1:650.000. Available at http://www.mineropar.pr.gov.br/modules/conteu do/conteudo.php?conteudo=76. Access October 2018.

REIMANN C., FILZMOSER P., GARRETT R.G. 2005. Background and threshold: critical comparison of methods of determination. Science of the Total Environment v. 346 1-16.

REINMANN C., FIMOSER P., FABIAN K., HRON K., BIRKE M., DEMETRIADES A., DINELLI E., LADERBERGER A., 2012. The concept of compositional data analysis in practice - Total major element concentrations in and grazing soils in Europe. Science of Total Environment, 426: 196-210.

SINCLAIR A.J., BLACKWELL G.H. 2005. Mineral Inventory Estimation. Cambridge Univ. Press. p. 380.

SMITH D., DEMETRIADES A., DE CARITAT P., XUEQIU WANG. 2018. The history, progress, and future of global-scale geochemical mapping. Geochimica Brasiliensis 32(2): 115135 ,

THOMPSON, M., HOWARTH, R.J. 1973.The rapid estimation and control of precision by duplicate determinations. The Analyst, 981973. 153-160.

THOMPSON, M., HOWARTH, R.J. $1976 \mathrm{a}$. Duplicate analysis in practice - Part 1. Theoretical approach and estimation of analytical reproducibility. The Analyst, 101 690-698.

THOMPSON, M., HOWARTH, R.J. 1976 b. Duplicate analysis in practice - Part 2. Examination of proposed methods and examples of its use. The Analyst, 101. 699-709.

SURFER 2002. Surface Mapping System. Golden Software, Inc.

WEAVER, T.A., BROXTON D.F., BOLIVAR S.L., FREEMAN S.H. 1983. The Geochemical Atlas of Alaska. Los Alamos: Los Alamos Nat. Lab. 


\section{APPENDIX 1}

Element contents in each sub-cell of the regular grid. Composite refer to the element content achieved by analyzing the composite samples (see item 2.2 ).

Original, $\dot{\mathrm{x}}$ and $\mathrm{Md}$ refer respectively to the arithmetic mean and to the median values of the previous analyses (see item 1.2) of the original samples (N) contained in each sub-cell.

\begin{tabular}{|c|c|c|c|c|c|c|c|c|c|c|c|c|}
\hline Sub-cell & Type of s & mple & $\mathrm{N}$ & $\begin{array}{c}\text { As } \\
\text { (ppm) }\end{array}$ & $\begin{array}{c}\mathrm{Co} \\
(\mathrm{ppm})\end{array}$ & $\begin{array}{c}\mathrm{Cu} \\
(\mathrm{ppm})\end{array}$ & $\begin{array}{c}\mathrm{F} \\
(\mathrm{ppm})\end{array}$ & $\begin{array}{l}\mathrm{Fe} \\
(\%)\end{array}$ & $\begin{array}{c}\mathrm{Mn} \\
(\mathrm{ppm})\end{array}$ & $\begin{array}{c}\mathrm{Ni} \\
(\mathrm{ppm})\end{array}$ & $\begin{array}{c}\mathrm{Pb} \\
(\mathrm{ppm})\end{array}$ & $\begin{array}{c}\mathrm{Zn} \\
(\mathrm{ppm})\end{array}$ \\
\hline \multirow{3}{*}{$323-\mathrm{D} / 33$} & \multicolumn{2}{|c|}{ Composite } & 1 & 0.5 & 17.4 & 33 & \multirow[t]{3}{*}{216} & \multirow[t]{3}{*}{3.25} & 900 & 20 & 13.4 & 85 \\
\hline & \multirow{2}{*}{ Original } & $\dot{\mathrm{x}}$ & \multirow{2}{*}{12} & 0.27 & 22.00 & 23.00 & & & 807.50 & 14.17 & 12.08 & 71.33 \\
\hline & & $\mathrm{Md}$ & & 0.25 & 19.5 & 18 & & & 635 & 14 & 12 & 73 \\
\hline \multirow{3}{*}{$323-\mathrm{D} / 34$} & \multicolumn{2}{|c|}{ Composite } & 1 & 0.5 & 15.6 & 29 & \multirow[t]{3}{*}{162} & \multirow[t]{3}{*}{4.78} & 1046 & 18 & 17.2 & 78 \\
\hline & \multirow{2}{*}{ Original } & $\dot{\mathrm{x}}$ & \multirow{2}{*}{76} & 1.22 & 16.22 & 16.24 & & & 976.91 & 12.29 & 17.89 & 66.26 \\
\hline & & Md & & 1 & 15.5 & 13 & & & 515 & 11.5 & 18 & 60 \\
\hline \multirow{3}{*}{$323-\mathrm{D} / 35$} & \multicolumn{2}{|c|}{ Composite } & 1 & 3 & 21.9 & 46 & 238 & 6.19 & 2623 & 24 & 16.5 & 91 \\
\hline & Orioinal & $\dot{\mathrm{x}}$ & 19 & 2.74 & 19.68 & 27.62 & & & 2428.75 & 19.21 & 23.59 & 73.78 \\
\hline & Uriginal & $\mathrm{Md}$ & 19 & 2 & 19 & 22 & & & 1500 & 18 & 22 & 68 \\
\hline & Compo & & 1 & 2 & 25 & 46 & 403 & 8.84 & 3044 & 29 & 17.6 & 92 \\
\hline $323-\mathrm{D} / 36$ & Orioinal & $\dot{\mathrm{x}}$ & 88 & 2.06 & 31.03 & 32.15 & & & 2563.86 & 31.90 & 24.64 & 84.15 \\
\hline & Uriginal & $\mathrm{Md}$ & 88 & 2 & 29.5 & 29 & & & 1750 & 30 & 25 & 84 \\
\hline & Compo & & 1 & 1 & 15 & 38 & 186 & 3.79 & 1952 & 21 & 11.4 & 62 \\
\hline $323-\mathrm{D} / 42$ & Original & $\dot{\mathrm{x}}$ & 94 & 0.65 & 14.77 & 22.04 & & & 1768.83 & 11.23 & 15.88 & 62.50 \\
\hline & Urigit & $\mathrm{Md}$ & 94 & 0.25 & 13 & 20 & & & 795 & 10 & 15 & 60 \\
\hline & Compo & & 1 & 1 & 21.1 & 52 & 166 & 4.37 & 1544 & 23 & 19.6 & 111 \\
\hline $323-\mathrm{D} / 43$ & Orioinal & $\dot{\mathrm{x}}$ & 63 & 0.89 & 11.97 & 18.29 & & & 927.14 & 9.70 & 18.37 & 65.63 \\
\hline & Uriginal & $\mathrm{Md}$ & 63 & 0.25 & 8 & 14 & & & 380 & 7 & 17 & 50 \\
\hline & Compo & & 1 & 2 & 16.3 & 29 & 317 & 4.72 & 2339 & 24 & 20.4 & 82 \\
\hline $323-\mathrm{D} / 44$ & Orioinal & $\dot{\mathrm{x}}$ & 72 & 1.61 & 13.41 & 15.07 & & & 1457.38 & 13.58 & 20.32 & 63.11 \\
\hline & Original & $\mathrm{Md}$ & 12 & 1 & 12 & 12 & & & 630 & 13 & 21 & 56 \\
\hline & Compo & & 1 & 5 & 20.9 & 48 & 487 & 5.27 & 2777 & 29 & 18.4 & 85 \\
\hline $323-\mathrm{D} / 45$ & Original & $\dot{\mathrm{x}}$ & 286 & 3.82 & 23.15 & 34.38 & & & 2700.03 & 21.12 & 22.18 & 78.99 \\
\hline & Original & $\mathrm{Md}$ & 280 & 4 & 21 & 25 & & & 1800 & 20 & 21 & 70 \\
\hline & Compo & & 1 & 3 & 14.9 & 31 & 353 & 3.98 & 3177 & 14 & 11.7 & 75 \\
\hline $323-\mathrm{D} / 51$ & Orioinal & $\dot{\mathrm{x}}$ & 140 & 1.53 & 20.20 & 23.35 & & & 3415.36 & 11.86 & 18.27 & 78.16 \\
\hline & Original & $\mathrm{Md}$ & 140 & 1 & 19 & 19 & & & 2300 & 12 & 16 & 73 \\
\hline & Compo & & 1 & 1 & 14.1 & 37 & 5308 & 3.76 & 1564 & 13 & 52.4 & 102 \\
\hline $323-\mathrm{D} / 52$ & Original & $\dot{\mathrm{x}}$ & 37 & 0.87 & 11.73 & 16.49 & & & 903.05 & 9.49 & 22.27 & 54.73 \\
\hline & Uriginal & $\mathrm{Md}$ & 31 & 0.25 & 10 & 16 & & & 440 & 6 & 21 & 50 \\
\hline & Compo & & 1 & 7 & 20.4 & 44 & 667 & 5.02 & 3536 & 27 & 18.9 & 79 \\
\hline $323-\mathrm{D} / 53$ & Orioinal & $\dot{\mathrm{x}}$ & 63 & 4.22 & 22.75 & 33.02 & & & 1913.02 & 19.71 & 23.51 & 92.27 \\
\hline & Uriginal & $\mathrm{Md}$ & 63 & 4 & 20 & 27 & & & 1300 & 19 & 20 & 86 \\
\hline & Compo & & 1 & 5 & 26.2 & 61 & 352 & 6.1 & 2123 & 36 & 13.8 & 102 \\
\hline $323-\mathrm{D} / 54$ & Orimingl & $\dot{\mathrm{x}}$ & & 4.71 & 27.38 & 43.19 & & & 2044.92 & 22.35 & 17.10 & 107.65 \\
\hline & Original & $\mathrm{Md}$ & 137 & 4 & 25 & 35.5 & & & 1500 & 20 & 16 & 100 \\
\hline & Compo & & 1 & 3 & 14.9 & 29 & 511 & 4.95 & 4073 & 18 & 14.1 & 97 \\
\hline $323-\mathrm{D} / 60$ & Original & $\dot{\mathrm{x}}$ & 185 & 2.61 & 14.76 & 20.06 & & & 2892.23 & 15.62 & 16.72 & 71.50 \\
\hline & Uriginal & $\mathrm{Md}$ & 185 & 2 & 14 & 16 & & & 1900 & 15 & 16 & 67 \\
\hline & Compo & & 1 & 4 & 15.8 & 25 & 384 & 4.81 & 3226 & 22 & 18.5 & 77 \\
\hline $323-\mathrm{D} / 61$ & Original & $\dot{\mathrm{x}}$ & 64 & 4.36 & 18.64 & 17.63 & & & 2381.72 & 16.88 & 23.38 & 67.23 \\
\hline & & $\mathrm{Md}$ & 04 & 3 & 18 & 16 & & & 1550 & 15 & 23.5 & 61 \\
\hline & Compo & & 1 & 6 & 23.5 & 54 & 464 & 5.31 & 1521 & 32 & 18 & 85 \\
\hline $323-\mathrm{D} / 62$ & & $\dot{\mathrm{x}}$ & 38 & 7.11 & 25.22 & 31.50 & & & 2001.21 & 20.70 & 22.94 & 77.75 \\
\hline & Uriginal & $\mathrm{Md}$ & 38 & 7.5 & 22.5 & 27.5 & & & 1600 & 18 & 23 & 70.5 \\
\hline & Compo & & 1 & 2 & 20.1 & 51 & 255 & 5.59 & 1592 & 23 & 21.3 & 70 \\
\hline $323-\mathrm{D} / 63$ & Original & $\dot{\mathrm{x}}$ & 71 & 2.58 & 24.79 & 26.53 & & & 2063.57 & 19.00 & 29.50 & 67.32 \\
\hline & Origit & $\mathrm{Md}$ & 11 & 2 & 19 & 20 & & & 710 & 17.5 & 27 & 61.5 \\
\hline & Compo & & 1 & 5 & 19.4 & 41 & 483 & 3.87 & 1713 & 27 & 18.8 & 75 \\
\hline $323-\mathrm{D} / 70$ & & $\dot{\mathrm{x}}$ & & 4.47 & 23.70 & 25.96 & & & 1194.63 & 17.59 & 19.59 & 64.19 \\
\hline & Original & $\mathrm{Md}$ & 81 & 4 & 21.5 & 18 & & & 800 & 18 & 19 & 61 \\
\hline & Compo & & 1 & 8 & 22.4 & 38 & 497 & 4.63 & 2883 & 27 & 28.9 & 107 \\
\hline $323-\mathrm{D} / 71$ & $O r$ & $\dot{\mathrm{x}}$ & 64 & 4.70 & 23.70 & 24.14 & & & 2602.19 & 16.30 & 15.59 & 70.10 \\
\hline & Or & $\mathrm{Md}$ & 64 & 4 & 21 & 20 & & & 1000 & 14 & 14 & 60 \\
\hline & Compo & & 1 & 6 & 27.1 & 42 & 487 & 5.03 & 4403 & 35 & 28.7 & 83 \\
\hline $323-\mathrm{D} / 72$ & Orioinal & $\dot{\mathrm{x}}$ & 13 & 6.23 & 30.46 & 21.92 & & & 2316.67 & 18.83 & 25.85 & 46.31 \\
\hline & Uriginal & $\mathrm{Md}$ & 13 & 7 & 32 & 16 & & & 1800 & 14.5 & 25 & 35 \\
\hline
\end{tabular}




\begin{tabular}{|c|c|c|c|c|c|c|c|c|c|c|c|c|}
\hline \multirow{3}{*}{$324-\mathrm{A} / 67$} & \multicolumn{2}{|c|}{ Composite } & 1 & 0.5 & \multirow{3}{*}{$\begin{array}{c}11 \\
14.08 \\
11\end{array}$} & \multirow{3}{*}{$\begin{array}{c}18 \\
7.99 \\
5.4\end{array}$} & \multirow{3}{*}{$\begin{array}{c}292 \\
388.24 \\
350\end{array}$} & \multirow{3}{*}{$\begin{array}{c}6.42 \\
4.90 \\
5\end{array}$} & 629 & 25 & 11.8 & 54 \\
\hline & \multirow{2}{*}{ Original } & \multirow{2}{*}{$\begin{array}{c}\dot{\mathrm{x}} \\
\mathrm{Md}\end{array}$} & \multirow{2}{*}{25} & \multirow{2}{*}{$\begin{array}{c}0.72 \\
0.5\end{array}$} & & & & & 465.60 & 14.60 & 16.98 & 39.43 \\
\hline & & & & & & & & & 311 & 14 & 13 & 40 \\
\hline & Compo & ite & 1 & 2 & 10.5 & 17 & 535 & 4.92 & 1133 & 23 & 40.5 & 91 \\
\hline $324-\mathrm{A} / 76$ & & $\dot{\mathrm{x}}$ & 98 & 1.56 & 15.35 & 11.20 & 728.75 & 3.60 & 761.75 & 15.69 & 50.75 & 92.79 \\
\hline & Original & $\mathrm{Md}$ & 98 & 1 & 15 & 8 & 487.5 & 2.72 & 410 & 15 & 14 & 45 \\
\hline & Compo & ite & 1 & 14 & 14.8 & 42 & 442 & 4.72 & 1635 & 31 & 563 & 85 \\
\hline $324-\mathrm{A} / 77$ & & $\dot{\mathrm{x}}$ & 62 & 11.18 & 16.65 & 34.99 & 529.36 & 2.95 & 1371.53 & 18.43 & 225.06 & 62.75 \\
\hline & Uriginal & $\mathrm{Md}$ & 62 & 2 & 13 & 27 & 450 & 2.96 & 746 & 17 & 30 & 45 \\
\hline & Compo & ite & 1 & 21 & 18.9 & 45 & 397 & 4.03 & 1681 & 45 & 58.9 & 74 \\
\hline $324-\mathrm{A} / 78$ & Orig & $\dot{\mathrm{x}}$ & 88 & 19.44 & 15.20 & 32.06 & & 3.16 & 1020.04 & 27.02 & 45.33 & 61.87 \\
\hline & 0 & $\mathrm{Md}$ & 88 & 17 & 14 & 30 & & 3.05 & 1000 & 27.5 & 28 & 65 \\
\hline & Compo & ite & 1 & 0.5 & 15.8 & 29 & 309 & 4.57 & 651 & 28 & 11.7 & 63 \\
\hline $324-\mathrm{C} / 01$ & & $\dot{\mathrm{x}}$ & & 0.82 & 6.99 & 13.14 & 696.15 & 2.36 & 648.45 & 10.82 & 14.29 & 50.74 \\
\hline & Original & $\mathrm{Md}$ & 38 & 0.75 & 7.5 & 10 & 620 & 2.32 & 460 & 10 & 14 & 48 \\
\hline & Compo & & 1 & 0.5 & 12.9 & 15 & 328 & 5.18 & 1086 & 30 & 10.8 & 50 \\
\hline $324-\mathrm{C} / 02$ & & $\dot{\mathrm{x}}$ & 124 & 1.01 & 7.12 & 7.51 & 935.48 & 2.59 & 768.82 & 12.33 & 12.47 & 36.09 \\
\hline & Orig & $\mathrm{Md}$ & 124 & 1 & 7 & 6 & 900 & 2.55 & 545 & 11.4 & 11 & 33.5 \\
\hline & Compo & & 1 & 1 & 13.8 & 19 & 314 & 4.67 & 737 & 30 & 11.3 & 49 \\
\hline $324-\mathrm{C} / 03$ & & $\dot{\mathrm{x}}$ & & 1.09 & 9.09 & 10.36 & 949.29 & 2.76 & 678.61 & 14.68 & 13.38 & 42.44 \\
\hline & Original & Md & 196 & 1 & 8.5 & 7 & 860 & 2.35 & 560 & 14.65 & 12.3 & 40 \\
\hline & Compo & & 1 & 13 & 14.6 & 28 & 431 & 3.41 & 1302 & 33 & 24.3 & 63 \\
\hline $324-\mathrm{C} / 04$ & & $\dot{\mathrm{x}}$ & & 2.22 & 21.00 & 15.93 & 1044.71 & 4.94 & 719.17 & 29.37 & 30.65 & 56.52 \\
\hline & Original & Md & 137 & 1 & 17.5 & 7 & 940 & 4.015 & 425 & 26 & 19 & 45 \\
\hline & Compo & & 1 & 31 & 18.1 & 44 & 511 & 3.72 & 2266 & 37 & 54.4 & 95 \\
\hline $324-\mathrm{C} / 05$ & & $\dot{\mathrm{x}}$ & & 13.00 & 11.87 & 34.77 & & 3.43 & 1067.05 & 25.57 & 52.91 & 77.96 \\
\hline & Original & Md & 77 & 14 & 11.5 & 32.4 & & 3.3 & 1000 & 24 & 32.5 & 80 \\
\hline & Compo & & 1 & 34 & 15.7 & 37 & 449 & 3.56 & 1239 & 35 & 37.4 & 74 \\
\hline $324-\mathrm{C} / 06$ & & $\dot{\mathrm{x}}$ & & 26.45 & 17.98 & 36.87 & & 3.83 & 1163.45 & 32.58 & 35.87 & 66.57 \\
\hline & Original & $\mathrm{Md}$ & 56 & 7 & 16.8 & 29.5 & & 3.635 & 840 & 23.8 & 24 & 65 \\
\hline & Compo & & 1 & 0.5 & 19.2 & 29 & 289 & 7.85 & 613 & 34 & 10.7 & 61 \\
\hline $324-\mathrm{C} / 10$ & & $\dot{\mathrm{x}}$ & & 0.78 & 11.48 & 17.41 & 1096.25 & 3.80 & 612.86 & 16.60 & 12.42 & 50.84 \\
\hline & Or1 & $\mathrm{Md}$ & כנ & 0.5 & 11.7 & 15 & 715 & 3.6 & 460 & 16 & 13 & 50 \\
\hline & Compo & & 1 & 0.5 & 17.2 & 22 & 277 & 6.42 & 618 & 42 & 10.9 & 59 \\
\hline $324-\mathrm{C} / 11$ & & $\dot{\mathrm{x}}$ & & 0.84 & 7.86 & 10.80 & 825.15 & 2.66 & 477.29 & 13.48 & 14.09 & 47.07 \\
\hline & Original & $\mathrm{Md}$ & 81 & 1 & 7.2 & 8 & 735 & 2.635 & 420 & 14 & 14 & 45 \\
\hline & Compo & & 1 & 7 & 16.6 & 41 & 262 & 4.1 & 793 & 24 & 19.7 & 52 \\
\hline $324-\mathrm{C} / 13$ & & $\dot{\mathrm{x}}$ & & 7.94 & 10.93 & 18.25 & & 5.37 & 1069.77 & 15.30 & 19.23 & 52.27 \\
\hline & Orıgina & $\mathrm{Md}$ & 18 & 3.5 & 10 & 16 & & 4.56 & 911 & 11.55 & 17 & 50 \\
\hline & Com & & 1 & 7 & 16.8 & 33 & 219 & 4.02 & 506 & 36 & 12.8 & 53 \\
\hline $324-\mathrm{C} / 18$ & & & & 8.28 & 23.99 & 36.93 & & 5.25 & 896.66 & 30.11 & 13.23 & 81.91 \\
\hline & Original & $\mathrm{Md}$ & 50 & 7.5 & 20 & 27 & & 3.8 & 670 & 28 & 13 & 85 \\
\hline & Compo & & 1 & 16 & 26 & 48 & 379 & 5.66 & 1982 & 46 & 29.2 & 102 \\
\hline $324-\mathrm{C} / 23$ & & $\dot{\mathrm{x}}$ & & 15.19 & 29.51 & 33.67 & & 5.38 & 2124.82 & 33.18 & 28.76 & 88.05 \\
\hline & Origin & $\mathrm{Md}$ & 41 & 13 & 27 & 31 & & 4.7 & 1900 & 32 & 22.5 & 82.5 \\
\hline & Compo & & 1 & 8 & 20 & 35 & 267 & 4.85 & 1191 & 35 & 24.8 & 62 \\
\hline $324-\mathrm{C} / 24$ & & $\dot{\mathrm{x}}$ & & 8.21 & 22.35 & 20.33 & & 3.78 & 1462.41 & 24.74 & 21.45 & 65.59 \\
\hline & $\mathrm{O}$ & Md & 55 & 3 & 20 & 18 & & 3.03 & 910 & 21 & 16 & 60 \\
\hline & Comp & ite & 1 & 2 & 10.1 & 20 & 211 & 1.68 & 435 & 24 & 14.6 & 38 \\
\hline $324-\mathrm{C} / 25$ & & $\dot{\mathrm{x}}$ & & 1.46 & 13.40 & 19.80 & & 2.78 & 734.93 & 17.02 & 16.59 & 49.59 \\
\hline & Origin & $\mathrm{Md}$ & 99 & 1 & 10 & 13 & & 2.45 & 420 & 12 & 13 & 45 \\
\hline & Compo & & 1 & 1 & 8.9 & 17 & 194 & 1.9 & 437 & 24 & 10.6 & 42 \\
\hline $324-\mathrm{C} / 26$ & Orioinal & $\dot{\mathrm{x}}$ & 154 & 1.43 & 9.41 & 10.64 & & 1.77 & 535.23 & 12.29 & 12.71 & 47.28 \\
\hline & ris & $\mathrm{Md}$ & 154 & 1 & 8 & 9 & & 1.64 & 415 & 11 & 11 & 36 \\
\hline & Compo & ite & 1 & 2 & 10.9 & 20 & 214 & 2.25 & 393 & 23 & 9 & 38 \\
\hline $324-\mathrm{C} / 27$ & & & & 1.91 & 10.53 & 13.09 & & 1.86 & 432.90 & 12.50 & 11.15 & 48.37 \\
\hline & Original & $\mathrm{Md}$ & 114 & 1 & 10 & 10.5 & & 1.65 & 390 & 10 & 10 & 41.5 \\
\hline & Compo & & 1 & 5 & 22 & 50 & 388 & 5.84 & 1479 & 37 & 13.5 & 80 \\
\hline $324-\mathrm{C} / 28$ & & $\dot{\mathrm{x}}$ & 78 & 3.75 & 21.24 & 29.91 & & 4.74 & 1488.99 & 22.60 & 19.50 & 76.31 \\
\hline & & $\mathrm{Md}$ & 78 & 3 & 19.5 & 28 & & 4.5 & 1020 & 18 & 18 & 72.5 \\
\hline & Com & & 1 & 8 & 19.9 & 53 & 241 & 5.01 & 1139 & 34 & 17.4 & 59 \\
\hline $324-\mathrm{C} / 29$ & & & & 7.95 & 15.07 & 29.76 & & 4.82 & 781.20 & 13.39 & 21.42 & 59.11 \\
\hline & Original & $\mathrm{Md}$ & 25 & 6.5 & 13 & 23 & & 4.9 & 650 & 10 & 18 & 59 \\
\hline & Compo & ite & 1 & 5 & 28 & 72 & 365 & 6.57 & 1433 & 41 & 21.1 & 79 \\
\hline $324-\mathrm{C} / 30$ & & $\dot{\mathrm{x}}$ & 5 & 16.76 & 13.94 & 37.33 & & 5.79 & 739.58 & 16.50 & 23.78 & 81.17 \\
\hline & C & $\mathrm{Md}$ & 5 & 16.76 & 13.94 & 37.33 & & 5.79 & 739.58 & 16.50 & 23.78 & 81.17 \\
\hline
\end{tabular}




\begin{tabular}{|c|c|c|c|c|c|c|c|c|c|c|c|c|}
\hline \multirow{3}{*}{$324-\mathrm{C} / 31$} & \multicolumn{2}{|c|}{ Composite } & 1 & \multirow{3}{*}{$\begin{array}{c}14 \\
10.77 \\
10.77\end{array}$} & \multirow{3}{*}{$\begin{array}{c}33.1 \\
26.45 \\
26.45 \\
\end{array}$} & \multirow{3}{*}{$\begin{array}{c}67 \\
39.10 \\
39.10 \\
\end{array}$} & \multirow[t]{3}{*}{340} & \multirow{3}{*}{$\begin{array}{l}7.16 \\
3.81 \\
3.81\end{array}$} & 2701 & 67 & 18.1 & 106 \\
\hline & \multirow{2}{*}{ Original } & \multirow{2}{*}{$\begin{array}{c}\dot{\mathrm{x}} \\
\mathrm{Md}\end{array}$} & \multirow{2}{*}{34} & & & & & & 1737.77 & 30.57 & 19.08 & 88.00 \\
\hline & & & & & & & & & 1737.77 & 30.57 & 19.08 & 88.00 \\
\hline & Compo & & 1 & 6 & 25.2 & 51 & 356 & 4.98 & 907 & 42 & 17.4 & 92 \\
\hline $324-\mathrm{C} / 32$ & Oriqinol & $\dot{\mathrm{x}}$ & 106 & 7.16 & 24.74 & 37.29 & & 2.91 & 952.49 & 26.77 & 21.08 & 81.71 \\
\hline & Original & $\mathrm{Md}$ & 106 & 6 & 23 & 32 & & 2.925 & 690 & 24 & 18 & 70 \\
\hline & Compo & ite & 1 & 4 & 13.7 & 28 & 264 & 3.01 & 1053 & 27 & 10.3 & 44 \\
\hline $324-\mathrm{C} / 33$ & & $\dot{\mathrm{x}}$ & & 4.01 & 11.94 & 14.20 & & 1.55 & 832.90 & 12.40 & 12.23 & 47.23 \\
\hline & Original & $\mathrm{Md}$ & 102 & 2 & 9 & 12 & & 1.6 & 416 & 9 & 12 & 46 \\
\hline & Compo & ite & 1 & 1 & 9.4 & 19 & 311 & 1.7 & 376 & 26 & 13.3 & 40 \\
\hline $324-\mathrm{C} / 34$ & Orioingl & $\dot{\mathrm{x}}$ & 242 & 1.71 & 9.83 & 10.50 & & 1.92 & 522.38 & 9.42 & 15.20 & 42.65 \\
\hline & Original & $\mathrm{Md}$ & 342 & 2 & 9 & 9 & & 1.6 & 430 & 9 & 12 & 39 \\
\hline & Compo & ite & 1 & 0.5 & 15.2 & 26 & 175 & 3.03 & 724 & 38 & 11.1 & 57 \\
\hline $324-\mathrm{C} / 35$ & & $\dot{\mathrm{x}}$ & & 1.20 & 10.70 & 10.90 & & 1.78 & 497.83 & 12.78 & 13.57 & 39.42 \\
\hline & Original & $\mathrm{Md}$ & 108 & 1 & 7 & 9 & & 1.5 & 430 & 10 & 13 & 31 \\
\hline & Compo & & 1 & 0.5 & 8.2 & 14 & 146 & 1.78 & 346 & 19 & 9.4 & 40 \\
\hline $324-\mathrm{C} / 36$ & Orioinal & $\dot{\mathrm{x}}$ & 82 & 0.71 & 6.45 & 6.65 & & 1.61 & 324.64 & 9.54 & 11.45 & 37.38 \\
\hline & Urig & $\mathrm{Md}$ & 82 & 0.5 & 5.5 & 5.5 & & 1.15 & 270 & 8 & 10 & 33 \\
\hline & Compo & ite & 1 & 8 & 21.2 & 56 & 287 & 5.4 & 1672 & 31 & 14 & 65 \\
\hline $324-\mathrm{C} / 37$ & & $\dot{\mathrm{x}}$ & & 11.14 & 19.22 & 34.25 & & 4.59 & 1538.31 & 17.41 & 20.99 & 65.97 \\
\hline & Original & $\mathrm{Md}$ & 147 & 9 & 18 & 28 & & 4.05 & 920 & 16 & 20 & 58 \\
\hline & Compo & & 1 & 16 & 34.8 & 82 & 278 & 7.17 & 2251 & 45 & 19.7 & 60 \\
\hline $324-\mathrm{C} / 38$ & & $\dot{\mathrm{x}}$ & & 15.78 & 26.11 & 40.82 & & 4.70 & 1487.60 & 20.69 & 24.32 & 63.54 \\
\hline & Original & Md & 16 & 15 & 19.5 & 39 & & 4.85 & 980 & 19 & 21 & 66 \\
\hline & Compo & & 1 & 8 & 35.7 & 74 & 212 & 6.05 & 1567 & 53 & 16 & 91 \\
\hline $324-\mathrm{C} / 39$ & & $\dot{\mathrm{x}}$ & & 8.38 & 26.41 & 50.50 & & 5.78 & 1328.38 & 34.91 & 19.21 & 84.82 \\
\hline & Original & Md & 22 & 6 & 21 & 49.5 & & 6.2 & 870 & 31 & 18.5 & 86 \\
\hline & Compo & & 1 & 3 & 28 & 65 & 193 & 5.21 & 1036 & 40 & 11.5 & 75 \\
\hline $324-\mathrm{C} / 40$ & & $\dot{\mathrm{x}}$ & & 3.37 & 20.72 & 40.45 & & 2.89 & 830.24 & 24.76 & 16.20 & 79.07 \\
\hline & Original & $\mathrm{Md}$ & 104 & 3 & 18 & 33 & & 2.85 & 720 & 22 & 16 & 81.5 \\
\hline & Compo & & 1 & 1 & 17.6 & 38 & 200 & 3.43 & 694 & 30 & 11.9 & 63 \\
\hline $324-\mathrm{C} / 41$ & & $\dot{\mathrm{x}}$ & 134 & 1.45 & 11.83 & 27.56 & & 2.02 & 705.25 & 15.71 & 16.30 & 72.06 \\
\hline & Original & Md & 134 & 1 & 12 & 24 & & 2 & 569 & 15 & 14 & 70 \\
\hline & Compo & & 1 & 43 & 43 & 43 & 43 & 43 & 43 & 43 & 43 & 43 \\
\hline $324-\mathrm{C} / 42$ & & $\dot{\mathrm{x}}$ & 45 & 1.85 & 11.39 & 16.35 & & 2.09 & 519.39 & 12.39 & 13.27 & 53.13 \\
\hline & Original & Md & 45 & 1 & 10 & 13 & & 1.9 & 361 & 11 & 13 & 53 \\
\hline & Compo & & 1 & 0.5 & 18.7 & 29 & 119 & 3.26 & 798 & 35 & 11.7 & 61 \\
\hline $324-\mathrm{C} / 43$ & & $\dot{\mathrm{x}}$ & & 1.27 & 16.19 & 13.98 & & 2.44 & 786.48 & 20.74 & 15.47 & 66.48 \\
\hline & Origina & $\mathrm{Md}$ & 55 & 0.75 & 13 & 12 & & 2.15 & 665 & 16.5 & 15 & 60 \\
\hline & Compo & & 1 & 0.5 & 20.1 & 25 & 97 & 3.68 & 1036 & 31 & 15.9 & 51 \\
\hline $324-\mathrm{C} / 44$ & Original & & 117 & 0.75 & 17.75 & 13.55 & & 2.77 & 798.45 & 17.67 & 18.82 & 49.07 \\
\hline & Orıgınal & $\mathrm{Md}$ & 117 & 0.5 & 15 & 10 & & 2.35 & 530 & 15 & 18 & 45.5 \\
\hline & Compo & & 1 & 0.5 & 18.8 & 30 & 123 & 3.56 & 610 & 29 & 14.5 & 65 \\
\hline $324-\mathrm{C} / 45$ & & $\dot{\mathrm{x}}$ & & 0.70 & 14.60 & 11.00 & & 2.89 & 557.59 & 22.00 & 18.10 & 64.33 \\
\hline & Origin & $\mathrm{Md}$ & 29 & 0.5 & 12 & 9.5 & & 2.3 & 380 & 20.5 & 18 & 58.5 \\
\hline & Com & & 1 & 5 & 30.7 & 55 & 188 & 5.83 & 2146 & 40 & 16.5 & 80 \\
\hline $324-\mathrm{C} / 46$ & & $\dot{\mathrm{x}}$ & & 6.31 & 33.38 & 44.69 & & 5.22 & 2033.58 & 30.48 & 20.71 & 83.11 \\
\hline & Original & $\mathrm{Md}$ & 172 & 4 & 30 & 38 & & 4.95 & 1592.5 & 26 & 19 & 80 \\
\hline & Compo & ite & 1 & 4 & 26.2 & 51 & 142 & 5.32 & 1544 & 38 & 19.3 & 63 \\
\hline $324-\mathrm{C} / 47$ & & $\dot{\mathrm{x}}$ & & 4.40 & 28.50 & 31.54 & & 3.41 & 1613.42 & 28.30 & 22.07 & 61.88 \\
\hline & Origin & $\mathrm{Md}$ & 80 & 3 & 25 & 28 & & 3.05 & 840 & 22 & 18.5 & 53.5 \\
\hline & Compo & & 1 & 3 & 18.9 & 45 & 108 & 4.26 & 1143 & 22 & 13.7 & 52 \\
\hline $324-\mathrm{C} / 48$ & & $\dot{\mathrm{x}}$ & & 3.86 & 19.05 & 23.76 & & 1.60 & 921.43 & 19.05 & 24.00 & 51.86 \\
\hline & Origin & $\mathrm{Md}$ & 14 & 3 & 16 & 19 & & 1.7 & 420 & 17 & 16 & 46 \\
\hline & Compo & ite & 1 & 0.5 & 12.6 & 23 & 190 & 2.36 & 705 & 21 & 6.9 & 36 \\
\hline $324-\mathrm{C} / 49$ & & & & 2.01 & 9.21 & 12.40 & & 1.52 & 636.21 & 11.43 & 9.76 & 53.64 \\
\hline & Original & $\mathrm{Md}$ & 31 & 2 & 6 & 11.5 & & 1.425 & 334.5 & 9 & 10 & 51.5 \\
\hline & Compo & & 1 & 0.5 & 12.5 & 28 & 91 & 2.3 & 377 & 18 & 7.5 & 34 \\
\hline $324-\mathrm{C} / 50$ & & $\dot{\mathrm{x}}$ & 21 & 2.41 & 9.33 & 21.05 & & 1.91 & 257.79 & 10.67 & 10.44 & 45.90 \\
\hline & Original & $\mathrm{Md}$ & 21 & 2 & 6.5 & 13 & & 1.475 & 200 & 9 & 10 & 42 \\
\hline & Compo & & 1 & 2 & 29.7 & 61 & 162 & 5.46 & 1484 & 38 & 16.1 & 72 \\
\hline $324-\mathrm{C} / 55$ & & $\dot{\mathrm{x}}$ & & 3.09 & 30.47 & 34.47 & & 3.92 & 1322.91 & 20.83 & 20.96 & 62.18 \\
\hline & Original & $\mathrm{Md}$ & 93 & 2 & 27 & 30.5 & & 3.8 & 750 & 17 & 18.5 & 58 \\
\hline & Compo & & 1 & 2 & 18.4 & 32 & 231 & 4.04 & 789 & 39 & 13.2 & 66 \\
\hline $324-\mathrm{D} / 02$ & & $\dot{\mathrm{x}}$ & 45 & 3.23 & 17.59 & 29.68 & & 3.95 & 700.16 & 31.13 & 13.18 & 83.18 \\
\hline & 0 & $\mathrm{Md}$ & 45 & 0.5 & 16 & 28 & & 3.4 & 700 & 29 & 13 & 80 \\
\hline
\end{tabular}




\begin{tabular}{|c|c|c|c|c|c|c|c|c|c|c|c|c|}
\hline \multirow{3}{*}{$324-\mathrm{D} / 03$} & \multicolumn{2}{|c|}{ Composite } & 1 & \multirow{3}{*}{$\begin{array}{c}2 \\
1.11 \\
0.5 \\
\end{array}$} & \multirow{3}{*}{$\begin{array}{c}19.1 \\
15.07 \\
14 \\
\end{array}$} & \multirow{3}{*}{$\begin{array}{c}32 \\
32.75 \\
16.5\end{array}$} & \multirow[t]{3}{*}{170} & \multirow{2}{*}{$\begin{array}{l}3.98 \\
3.11\end{array}$} & \multirow{3}{*}{$\begin{array}{c}680 \\
518.32 \\
460 \\
\end{array}$} & \multirow{3}{*}{$\begin{array}{c}42 \\
34.77 \\
26\end{array}$} & \multirow{3}{*}{$\begin{array}{c}13.3 \\
12.96 \\
12 \\
\end{array}$} & \multirow{3}{*}{$\begin{array}{c}77 \\
64.41 \\
50 \\
\end{array}$} \\
\hline & \multirow{2}{*}{ Original } & \multirow{2}{*}{$\begin{array}{c}\dot{\mathrm{x}} \\
\mathrm{Md}\end{array}$} & \multirow{2}{*}{37} & & & & & & & & & \\
\hline & & & & & & & & 2.7 & & & & \\
\hline \multirow{3}{*}{$324-\mathrm{D} / 10$} & \multicolumn{2}{|c|}{ Composite } & 1 & 2 & 12.4 & 34 & 160 & 3.4 & 561 & 20 & 15.6 & 49 \\
\hline & \multirow{2}{*}{ Original } & $\dot{\mathrm{x}}$ & \multirow{2}{*}{77} & 2.40 & 13.27 & 19.88 & & 2.81 & 540.76 & 12.93 & 16.06 & 57.79 \\
\hline & & $\mathrm{Md}$ & & 2 & 14 & 19 & & 2.65 & 465 & 12 & 15.5 & 51.5 \\
\hline \multirow{3}{*}{$324-\mathrm{D} / 11$} & \multicolumn{2}{|c|}{ Composite } & 1 & 0.5 & 17.9 & 25 & 254 & 4.08 & 836 & 38 & 15.2 & 82 \\
\hline & \multirow{2}{*}{ Original } & $\dot{\mathrm{x}}$ & \multirow{2}{*}{374} & 1.30 & 18.93 & 18.45 & 362.47 & 3.02 & 630.14 & 24.98 & 19.20 & 80.22 \\
\hline & & $\mathrm{Md}$ & & 1 & 17 & 17 & 329.5 & 2.75 & 490 & 23 & 15 & 70 \\
\hline \multirow{3}{*}{$324-\mathrm{D} / 12$} & \multicolumn{2}{|c|}{ Composite } & 1 & 0.5 & 14.7 & 27 & 190 & 3.19 & 785 & 35 & 20.8 & 74 \\
\hline & \multirow{2}{*}{ Original } & $\dot{\mathrm{x}}$ & 139 & 0.84 & 14.92 & 20.59 & 349.09 & 2.48 & 713.41 & 20.43 & 22.67 & 67.48 \\
\hline & & $\mathrm{Md}$ & 139 & 1 & 16 & 19 & 320 & 2.34 & 474 & 16.8 & 17 & 59 \\
\hline & Compo & & 1 & 0.5 & 13.5 & 18 & 152 & 2.98 & 659 & 40 & 11.7 & 78 \\
\hline $324-\mathrm{D} / 19$ & & $\dot{\mathrm{x}}$ & & 2.24 & 12.01 & 12.82 & 255.22 & 2.03 & 449.75 & 20.28 & 12.51 & 69.05 \\
\hline & Original & $\mathrm{Md}$ & 103 & 2 & 11.5 & 12 & 256 & 1.9 & 430 & 17 & 12 & 65 \\
\hline & Compo & & 1 & 0.5 & 15.9 & 26 & 269 & 3.85 & 693 & 35 & 14.5 & 77 \\
\hline $324-\mathrm{D} / 20$ & & $\dot{\mathrm{x}}$ & 196 & 0.92 & 15.55 & 20.26 & 413.02 & 2.38 & 524.19 & 21.05 & 16.65 & 75.03 \\
\hline & Orıginal & $\mathrm{Md}$ & 196 & 1 & 15 & 20 & 396 & 2.275 & 470 & 20 & 15 & 72 \\
\hline & Con & & 1 & 0.5 & 10.4 & 23 & 190 & 3.05 & 541 & 23 & 19.2 & 71 \\
\hline $324-\mathrm{D} / 21$ & & $\dot{x}$ & & 0.67 & 14.10 & 19.03 & 352.14 & 4.28 & 790.45 & 31.57 & 14.54 & 63.91 \\
\hline & $\mathrm{O}$ & $\mathrm{Md}$ & 16 & 0.7 & 12.1 & 18 & 354 & 3.27 & 700 & 26 & 10.19 & 60 \\
\hline & Comp & & 1 & 0.5 & 13 & 17 & 163 & 2.3 & 462 & 37 & 20.1 & 75 \\
\hline $324-\mathrm{D} / 28$ & & $\dot{x}$ & & 1.14 & 11.89 & 7.82 & & 1.50 & 367.66 & 15.94 & 20.17 & 60.10 \\
\hline & Origin & $\mathrm{Md}$ & 78 & 1 & 10 & 7.5 & & 1.4 & 350 & 14 & 17.5 & 60 \\
\hline & Coml & & 1 & 0.5 & 24.5 & 23 & 131 & 4.28 & 703 & 50 & 13.6 & 76 \\
\hline $324-D / 29$ & & $\dot{\mathrm{x}}$ & & 1.00 & 25.00 & 15.59 & & 3.49 & 733.64 & 31.09 & 21.71 & 53.56 \\
\hline & Origin & $\mathrm{Md}$ & 10 & 1 & 15 & 16 & & 3 & 720 & 22 & 20 & 57.5 \\
\hline & Com & & 1 & 0.5 & 19.2 & 18 & 119 & 3.78 & 1033 & 41 & 12.4 & 69 \\
\hline $324-\mathrm{D} / 37$ & & $\dot{\mathrm{x}}$ & & 1.10 & 15.05 & 8.35 & & 2.54 & 614.32 & 19.27 & 18.36 & 58.41 \\
\hline & Origina & $\mathrm{Md}$ & 37 & 1 & 12 & 6.5 & & 1.8 & 400 & 16 & 18 & 38 \\
\hline & Compo & & 1 & 0.5 & 33.7 & 36 & 212 & 5.81 & 806 & 86 & 14.1 & 94 \\
\hline $324-D / 38$ & & $\dot{\mathrm{x}}$ & 53 & 1.07 & 25.25 & 18.44 & & 3.56 & 465.44 & 42.30 & 18.74 & 90.07 \\
\hline & Original & $\mathrm{Md}$ & 53 & 1 & 27 & 22 & & 4.2 & 520 & 43 & 17 & 84 \\
\hline & Compo & & 1 & 0.5 & 27.4 & 35 & 269 & 6.34 & 734 & 50 & 17.7 & 112 \\
\hline $324-\mathrm{D} / 39$ & Orioina & $\dot{\mathrm{x}}$ & 118 & 0.73 & 22.84 & 16.97 & & 4.96 & 591.34 & 27.47 & 21.50 & 114.24 \\
\hline & Original & $\mathrm{Md}$ & 118 & 0.5 & 21 & 15 & & 4.3 & 570 & 23 & 20 & 89 \\
\hline
\end{tabular}


APPENDIX 2

\begin{tabular}{|c|c|c|c|c|c|c|c|c|}
\hline Variable & Unit & Lowest & $\begin{array}{c}1^{\text {st }} \\
\text { quartile }\end{array}$ & Median & Average & $\begin{array}{c}3^{\text {rd }} \\
\text { quartile } \\
\end{array}$ & Highest & $\begin{array}{l}\text { Standard } \\
\text { deviation }\end{array}$ \\
\hline Ag & ppm & 0.0055 & 0.0055 & 0.0055 & 0.0055 & 0.0055 & 0.0055 & 0 \\
\hline Al & $\%$ & 0.59 & 0.995 & 1.26 & 1.319 & 1.525 & 3.36 & 0.509289 \\
\hline As & ppm & 0.55 & 0.55 & 2 & 4.477 & 5.5 & 34 & 6.367699 \\
\hline $\mathbf{A u}$ & $\mathrm{ppb}$ & 2.75 & 2.75 & 2.75 & 6.433 & 2.75 & 168 & 19.3889 \\
\hline B & ppm & 5.5 & 5.5 & 5.5 & 5.5 & 5.5 & 5.5 & 0 \\
\hline $\mathbf{B a}$ & ppm & 229 & 444.5 & 595 & 722 & 962 & 1720 & 362.8094 \\
\hline $\mathbf{B e}$ & ppm & 0.9 & 1.9 & 2.2 & 4.496 & 2.5 & 170 & 19.38187 \\
\hline $\mathbf{B i}$ & ppm & 0.03 & 0.13 & 0.18 & 0.2443 & 0.265 & 2.34 & 0.275599 \\
\hline $\mathbf{C a}$ & $\%$ & 0.04 & 0.11 & 0.14 & 0.2367 & 0.235 & 1.74 & 0.269831 \\
\hline Cd & ppm & 0.03 & 0.06 & 0.08 & 0.09027 & 0.1 & 0.52 & 0.060403 \\
\hline $\mathrm{Ce}$ & ppm & 34 & 57.15 & 73.4 & 81.08 & 95.05 & 248.5 & 33.82458 \\
\hline Co & ppm & 8.2 & 14.65 & 18.1 & 18.92 & 21.95 & 35.7 & 6.381117 \\
\hline $\mathrm{Cr}$ & ppm & 16 & 29.5 & 43 & 48.36 & 58.5 & 178 & 27.6257 \\
\hline Cs & ppm & 0.96 & 1.92 & 2.85 & 3.188 & 4.19 & 8.17 & 1.620473 \\
\hline $\mathrm{Cu}$ & ppm & 14 & 25.5 & 33 & 36.72 & 46 & 82 & 15.29579 \\
\hline Dy & ppm & 1.84 & 2.985 & 3.53 & 3.752 & 4.27 & 7.31 & 1.185838 \\
\hline $\mathbf{E r}$ & ppm & 0.98 & 1.8 & 2.18 & 2.313 & 2.73 & 5.44 & 0.873055 \\
\hline $\mathbf{E u}$ & ppm & 0.54 & 0.87 & 0.96 & 1.042 & 1.21 & 2.18 & 0.311335 \\
\hline $\mathbf{F}$ & ppm & 91 & 187 & 262 & 345.1 & 360.5 & 5308 & 594.1555 \\
\hline $\mathrm{Fe}$ & $\%$ & 1.68 & 3.495 & 4.37 & 4.457 & 5.315 & 8.84 & 1.462633 \\
\hline $\mathbf{G a}$ & ppm & 8.7 & 14.15 & 17.3 & 16.59 & 19 & 23.3 & 3.254609 \\
\hline Gd & ppm & 2.38 & 3.61 & 4.07 & 4.426 & 5.23 & 8.44 & 1.293823 \\
\hline Ge & ppm & 0.055 & 0.055 & 0.055 & 0.0562 & 0.055 & 0.1 & 0.007299 \\
\hline Hf & ppm & 4.37 & 8.24 & 12.7 & 19.29 & 24.06 & 98.98 & 17.95158 \\
\hline Hg & ppm & 0.02 & 0.05 & 0.06 & 0.08333 & 0.105 & 0.24 & 0.047713 \\
\hline Но & ppm & 0.34 & 0.595 & 0.71 & 0.7572 & 0.845 & 1.6 & 0.260299 \\
\hline In & ppm & 0.011 & 0.025 & 0.03 & 0.04517 & 0.04 & 0.37 & 0.058045 \\
\hline $\mathbf{K}$ & $\%$ & 0.04 & 0.12 & 0.15 & 0.1735 & 0.21 & 0.48 & 0.083577 \\
\hline La & ppm & 17.9 & 28.05 & 35.7 & 40.17 & 46.95 & 127.7 & 17.53723 \\
\hline $\mathbf{L i}$ & ppm & 7 & 9.5 & 11 & 12.19 & 14 & 24 & 3.596896 \\
\hline $\mathbf{L u}$ & ppm & 0.17 & 0.29 & 0.34 & 0.3944 & 0.44 & 1.25 & 0.189439 \\
\hline Mg & $\%$ & 0.09 & 0.175 & 0.23 & 0.2647 & 0.315 & 0.76 & 0.133804 \\
\hline Mn & ppm & 346 & 693.5 & 1053 & 1365 & 1676 & 4403 & 920.3308 \\
\hline Mo & ppm & 0.0275 & 0.25 & 0.48 & 0.5579 & 0.635 & 4.05 & 0.609189 \\
\hline $\mathbf{N a}$ & $\%$ & 0.0055 & 0.0055 & 0.01 & 0.01077 & 0.02 & 0.03 & 0.006456 \\
\hline Nb & ppm & 13.87 & 19.85 & 25.38 & 29.55 & 33.56 & 91.04 & 14.52524 \\
\hline $\mathbf{N i}$ & ppm & 13 & 24 & 31 & 32.43 & 38 & 86 & 11.58537 \\
\hline $\mathbf{P}$ & ppm & 27.5 & 306 & 401 & 441.3 & 548 & 1239 & 219.0937 \\
\hline $\mathbf{P b}$ & ppm & 6.9 & 11.85 & 15.6 & 25.11 & 19.45 & 563 & 63.70217 \\
\hline Pd & $\mathrm{ppb}$ & 2.75 & 2.75 & 2.75 & 2.75 & 2.75 & 2.75 & 0 \\
\hline Pr & ppm & 3.67 & 5.69 & 7.38 & 8 & 9.605 & 19.58 & 3.082955 \\
\hline $\mathbf{P t}$ & ppb & 2.75 & 2.75 & 2.75 & 3.787 & 3.875 & 10 & 1.89625 \\
\hline $\mathbf{R b}$ & ppm & 32.4 & 67.5 & 79.6 & 84.14 & 100.8 & 164 & 26.25101 \\
\hline $\mathbf{R e}$ & ppm & 0.055 & 0.055 & 0.055 & 0.055 & 0.055 & 0.055 & 0 \\
\hline $\mathbf{S}$ & $\%$ & 0.0055 & 0.01 & 0.01 & 0.01031 & 0.01 & 0.02 & 0.00425 \\
\hline Sb & ppm & 0.0275 & 0.08 & 0.2 & 0.4674 & 0.465 & 5.35 & 0.812105 \\
\hline Sc & ppm & 1.8 & 4.35 & 5.6 & 6.451 & 7.95 & 15 & 2.88038 \\
\hline Se & ppm & 0.55 & 0.55 & 0.55 & 0.55 & 0.55 & 0.55 & 0 \\
\hline Sm & ppm & 2.4 & 3.85 & 4.9 & 5.068 & 6 & 9.6 & 1.595023 \\
\hline Sn & ppm & 0.7 & 1.7 & 2.2 & 2.943 & 2.8 & 30 & 3.604958 \\
\hline $\mathrm{Sr}$ & ppm & 24.1 & 53.75 & 91 & 158.5 & 171.4 & 792.1 & 176.7956 \\
\hline $\mathbf{T a}$ & ppm & 0.0275 & 0.1788 & 1.37 & 1.566 & 2.265 & 6.18 & 1.449313 \\
\hline $\mathbf{T b}$ & ppm & 0.34 & 0.51 & 0.62 & 0.6524 & 0.79 & 1.2 & 0.190574 \\
\hline $\mathbf{T e}$ & ppm & 0.0275 & 0.0275 & 0.0275 & 0.0424 & 0.04375 & 0.18 & 0.030694 \\
\hline Th & ppm & 4.9 & 8.75 & 11.4 & 12.9 & 15.7 & 29.8 & 5.538648 \\
\hline $\mathbf{T i}$ & $\%$ & 0.02 & 0.07 & 0.12 & 0.1296 & 0.17 & 0.33 & 0.070317 \\
\hline $\mathbf{T l}$ & ppm & 0.1 & 0.15 & 0.18 & 0.1941 & 0.22 & 0.47 & 0.06611 \\
\hline $\mathbf{T m}$ & ppm & 0.14 & 0.27 & 0.32 & 0.3515 & 0.4 & 0.94 & 0.148358 \\
\hline $\mathbf{U}$ & ppm & 1.19 & 2.09 & 2.59 & 2.897 & 3.19 & 7.92 & 1.203995 \\
\hline $\mathbf{V}$ & ppm & 15 & 46.5 & 82 & 91.08 & 132.5 & 222 & 51.29268 \\
\hline $\mathbf{W}$ & ppm & 0.055 & 0.055 & 2.3 & 2.504 & 3.6 & 10.8 & 2.303345 \\
\hline $\mathbf{Y}$ & ppm & 9.34 & 17.14 & 19.56 & 20.96 & 22.83 & 52.89 & 7.341863 \\
\hline Yb & ppm & 1.1 & 1.9 & 2.2 & 2.485 & 2.8 & 7.2 & 1.102907 \\
\hline $\mathbf{Z n}$ & ppm & 34 & 59 & 74 & 71.35 & 84 & 112 & 19.39594 \\
\hline $\mathbf{Z r}$ & ppm & 196.7 & 329.4 & 483.9 & 793 & 961.8 & 4215 & 757.6003 \\
\hline
\end{tabular}

